\title{
Can CFD Analysis Help PEM Fuel Cell Design and Operation?
}

Created by: Maher Al-baghdadi

Version received: 23 April 2020

Polymer electrolyte membrane (PEM) fuel cell system is an advanced power system for the future that is sustainable, clean and environmental friendly. PEM fuel cells are growing in importance as sources of sustainable energy and will doubtless form part of the changing program of energy resources in the future. PEM fuel cells are still undergoing intense development, and the combination of new and optimized materials, improved product development, novel architectures, more efficient transport processes, and design optimization and integration are expected to lead to major gains in performance, efficiency, reliability, manufacturability and cost-effectiveness.

The difficult experimental environment of PEM fuel cell systems has stimulated efforts to develop models that could simulate and predict multi-dimensional coupled transport of reactants, heat and charged species using computational fluid dynamic (CFD) technology. The strength of the CFD numerical approach is in providing detailed insight into the various transport mechanisms and their interaction, and in the possibility of performing parameters sensitivity analyses. The results of CFD analyses are relevant in: conceptual studies of new designs, detailed product development, troubleshooting, and redesign. CFD analysis complements testing and experimentation, by reduces the total effort required in the experiment design and data acquisition. Relevant case studies and recent progress in CFD techniques used in PEM fuel cell development have been presented and analyzed. The CFD models are shown to be able to provide a computer-aided tool for design and optimize future PEM fuel cell with much higher power density, long cell life, and lower cost.

\section{Historical background}

One of the earliest mathematical writings is the Babylonian tablet YBC 7289, which gives a sexagesimal numerical approximation of square root, the length of the diagonal in a unit square. Babylonians in this clay tablet have been used algorithms to compute side lengths of right-angled triangles into areas, and vice versa, similar to our contemporary numerical methods of analysis. The Babylonian method is numerically stable, it is converges fast regardless of the initial guess, while Method $X$ is extremely slowly and hence numerically unstable [1]. Numerical analysis continues this long tradition of practical mathematical calculations. Much like the Babylonian approximation of square root, modern numerical analysis does not seek exact answers, because exact answers are often impossible to obtain in practice. Instead, much of numerical analysis is concerned with obtaining approximate solutions while maintaining reasonable bounds on errors. These consist of splitting the volume that is being analyzed (say the material of a beam, or the air in a room) into small elements (typically Platonic solids like prisms or tetrahedral). It is interesting to think that this so-called "meshing" in the engineering world, or splitting a calculation into small portions, was already applied by the old Babylonians. Nowadays, in a very similar manner, computers are used to find the distribution of properties (e.g., stress, deflection, etc.) along a material (e.g., a metal beam), or even the displacement of fluids through volumes (i.e., computational fluid dynamics) 1 ].

\section{Advantages of computational fluid dynamics}

Computational Fluid Dynamics (CFD) is the sciences of predicting fluid flow, heat transfer, mass transfer, phase change, chemical reaction, mechanical movement, stress or deformation of related solid structures, and related phenomena by solving the mathematical equations that govern these processes using a numerical algorithm on a computer. The results of CFD are relevant in: conceptual studies of new designs, detailed product development, troubleshooting, and redesign. CFD complements testing and experimentation, by reduces the total effort required in the experiment design and data acquisition. CFD complements physical modeling and other experimental techniques 
by providing a detailed look into our engineering problems, including complex physical processes such as turbulence, chemical reactions, heat and mass transfer, and multiphase flows. Simulations can readily be done of physical phenomena that are difficult to measure, for example, full scale situations, environmental effects and hazards. In many cases, we can build and analyze virtual models at a fraction of the time and cost of physical modeling. This allows us to investigate more design options and "what if" scenarios than ever before. Moreover, flow modeling provides insights into our fluid flow problems that would be too costly or simply prohibitive by experimental techniques alone. The added insight and understanding gained from flow modeling gives us confidence in our design proposals, avoiding the added costs of over-sizing and over-specification, while reducing risk [2].

There are many advantages in considering CFD. Firstly, the theoretical development of the computational sciences focuses on the construction and solution of the governing equations and the study of various approximations to these equations. CFD presents the perfect opportunity to study specific terms in the governing equations in a more detailed fashion. New paths of theoretical development are realized, which could not have been possible without the introduction of this branch of computational approach. Secondly, CFD complements experimental and analytical approaches by providing an alternative cost-effective means of simulating real-life system. Particularly, CFD substantially reduces lead times and costs in designs and production compared to experimental-based approach and offers the ability to solve a range of complicated problems where the analytical approach is lacking. These advantages are realized through the increasing performance power in computer hardware and its declining costs. Thirdly, CFD has the capacity of simulating flow conditions that are not reproducible in experimental tests found in geophysical and biological fluid dynamics, such as nuclear accident scenarios or scenarios that are too huge or too remote to be simulated experimentally (e.g., Indonesian Tsunami of 2004). Fourthly, CFD can provide rather detailed, visualized, and comprehensive information when compared to analytical and experimental fluid dynamics. Actually, one of the main advantages of CFD is that the user has an almost unlimited choice of the level of detail of the results. Table 1. shows the comparison of experiment and CFD simulation in engineering applications [2].

Table 1. Comparison of experiment and CFD simulation in engineering applications.

\begin{tabular}{|c|c|}
\hline Experiments & CFD simulation \\
\hline $\begin{array}{l}\text { Quantitative description of flow } \\
\text { phenomena using measurements. } \\
\text { - for one quantity at a time } \\
\text { - at a limited number of points and } \\
\text { time instants } \\
\text { - for a laboratory-scale model } \\
\text { - for a limited range of problems and } \\
\text { - operating conditions } \\
\text { - expensive } \\
\text { - slow } \\
\text { - sequential } \\
\text { - single-purpose } \\
\text { Equipment and personnel are difficult to } \\
\text { transport. }\end{array}$ & $\begin{array}{l}\text { Quantitative prediction of flow phenomena } \\
\text { using CFD software. } \\
\text { - for all desired quantities } \\
\text { - with high resolution in space and time } \\
\text { - for the actual flow domain } \\
\text { - for virtually any problem and realistic } \\
\text { - operating conditions } \\
\text { - cheap(er) } \\
\text { - past(er) } \\
\text { - mulallel } \\
\text { CFD software is portable, easy to use and } \\
\text { modify. }\end{array}$ \\
\hline $\begin{array}{l}\text { Error sources: measurement errors, flow } \\
\text { disturbances by the probes, complexity. }\end{array}$ & $\begin{array}{l}\text { Error sources: modeling, discretization, } \\
\text { iteration, implementation. }\end{array}$ \\
\hline
\end{tabular}

\section{PEM fuel cell}

Fuel cell system is an advanced power system for the future that is sustainable, clean and environmental friendly. Fuel cells are growing in importance as sources of sustainable energy and will doubtless form part of the changing program 
of energy resources in the future. Among all kinds of fuel cells, polymer electrolyte membrane (PEM) fuel cells are compact and lightweight, work at low temperatures with a high output power density and low environmental impact, and offer superior system start-up and shutdown performance. These advantages have sparked development efforts in various quarters of industry to open up new field of applications for PEM fuel cells, including transportation power supplies, compact cogeneration stationary power supplies, portable power supplies, and emergency and disaster backup power supplies. Three key issues limiting the widespread commercialization of PEM fuel cell technology are better performance, long cell life, and lower cost.

The PEM fuel cell consists of a current collector (including gas channels), gas diffusion layer (GDL), and catalyst layer $(\mathrm{CL})$ on the anode and cathode sides as well as an ion conducting polymer membrane. Although a PEM fuel cell seems to be a very simple device, numerous processes take place simultaneously. It is therefore important to understand those processes, their mutual interdependence, and their dependence on components design and materials properties. Figure 1 shows the processes take place inside the PEM fuel cell. Obviously, the design of the components and properties of materials must accommodate these processes with minimum obstruction and losses. Because in some of the components more than one process takes place, very often with conflicting requirements, the properties and the design must be optimized. For example, the gas diffusion layer must be optimized so that the reactant gas may easily diffuse, yet at the same time that water, which travels in the opposite direction, does not accumulate in the pores. On top of that, the diffusion layer (or current collector layer as it is sometimes called) must be both electrically and thermally conductive. Similar requirements may be established for almost every fuel cell component.

The performance of PEM fuel cells is known to be influenced by many parameters, such as operating temperature, pressure, stoichiometric flow ratio, gas channels width, GDL thickness, membrane thickness, GDL porosity, material properties, clamping pressure, and GDL thermal conductivity, etc. In order to improve fuel cell performances, it is essential to understand these parametric effects on fuel cell operations. Changing the cell operating parameters can have either a beneficial or a detrimental impact on fuel cell performance [3]

Durability is one of the most critical remaining issues impeding successful commercialization of broad PEM fuel cell transportation energy applications, and the durability of fuel cell stack components remains, in most cases, insufficiently understood. Lengthy required testing times, lack of understanding of most degradation mechanisms, and the difficulty of performing in-situ, non-destructive structural evaluation of key components makes the topic a difficult one. The need for improved lifetime of PEM fuel cells necessitates that the failure mechanisms be clearly understood and life prediction models be developed, so that new designs can be introduced to improve long-term performance [2], [3], [4].

The stacking design and cell assembly parameters significantly affect the lifetime and performance of fuel cells. Adequate contact pressure is needed to hold together the fuel cell stack components to prevent leaking of the reactants, and minimize the contact resistance between layers. Every stacking design has a unique assembly pressure due to differences in fuel cell materials and stack design. The required clamping force is equal to the force required to compress the fuel cell layers adequately while not impeding flow. The assembly pressure affects the characteristics of the contact interfaces between components. If inadequate or non-uniform assembly pressure is used, there will be stack-sealing problems, such as fuel leakage, internal combustion, and unacceptable contact resistance. Too much pressure may impede flow through the GDL, or damage the MEA, resulting in a broken porous structure and a blockage of the gas diffusion passage. In both cases, the clamping pressure can decrease the cell performance and lifetime. Due to thin dimensions and the low mechanical strength of the electrodes and electrolyte layer versus the gaskets, bipolar plates, and end plates, the most important goal in the stack design and assembly is to achieve a proper and uniform pressure distribution [2].

The presence of microelectromechanical system (MEMS) technology makes it possible to manufacture the miniaturized fuel cell systems for application in portable electronic devices. The majority of research on micro-scale fuel cells is aimed at micro-power applications. There are many new miniaturized applications which can only be realized if a higher energy density power source is available compared to button cells and other small batteries. In small-scale applications, the fuel cell should be exceptionally small and have highest energy density. A key advantage 
of fuel cells for such applications is the much longer continuous operation and almost instantaneous refueling (as opposed to the recharging time required by batteries). The viability of PEM fuel cells as battery replacements requires that PEM fuel cells undergo significant miniaturization while achieving higher power densities. One way to achieve these requirements is to reduce the thickness of the cell (compacted-design) for increasing the volumetric power density of a fuel cell power supply. This presents challenges for small scale and micro-fuel cells in terms of design, materials, effective transport of reactants, and heat management $[2]$.

PEM fuel cells are still undergoing intense development, and the combination of new and optimized materials, improved product development, novel architectures, more efficient transport processes, and design optimization and integration are expected to lead to major gains in performance, efficiency, durability, reliability, manufacturability and cost-effectiveness. The development of physically representative models that allow a reliable simulation of the processes under realistic conditions is essential to the development and optimization of fuel cells, improve long-term performance and lifetime, the introduction of cheaper materials and fabrication techniques, manufacture the miniaturized fuel cell systems, stack design and cell assembly process, and the design and development of novel architectures. The difficult experimental environment of fuel cell systems has stimulated efforts to develop models that could simulate and predict multi-dimensional coupled transport of reactants, heat and charged species using CFD technology. CFD technology can be efficiently employed to develop a deeper understanding of the complex interaction between the fuel cell components and the processes that occur inside it. The strength of the CFD numerical approach is in providing detailed insight into the various transport mechanisms and their interaction, and in the possibility of performing parameters sensitivity analyses [2]. These CFD models allow engineers and designers to predict the performance of the fuel cell given design parameters, material properties and operating conditions. 


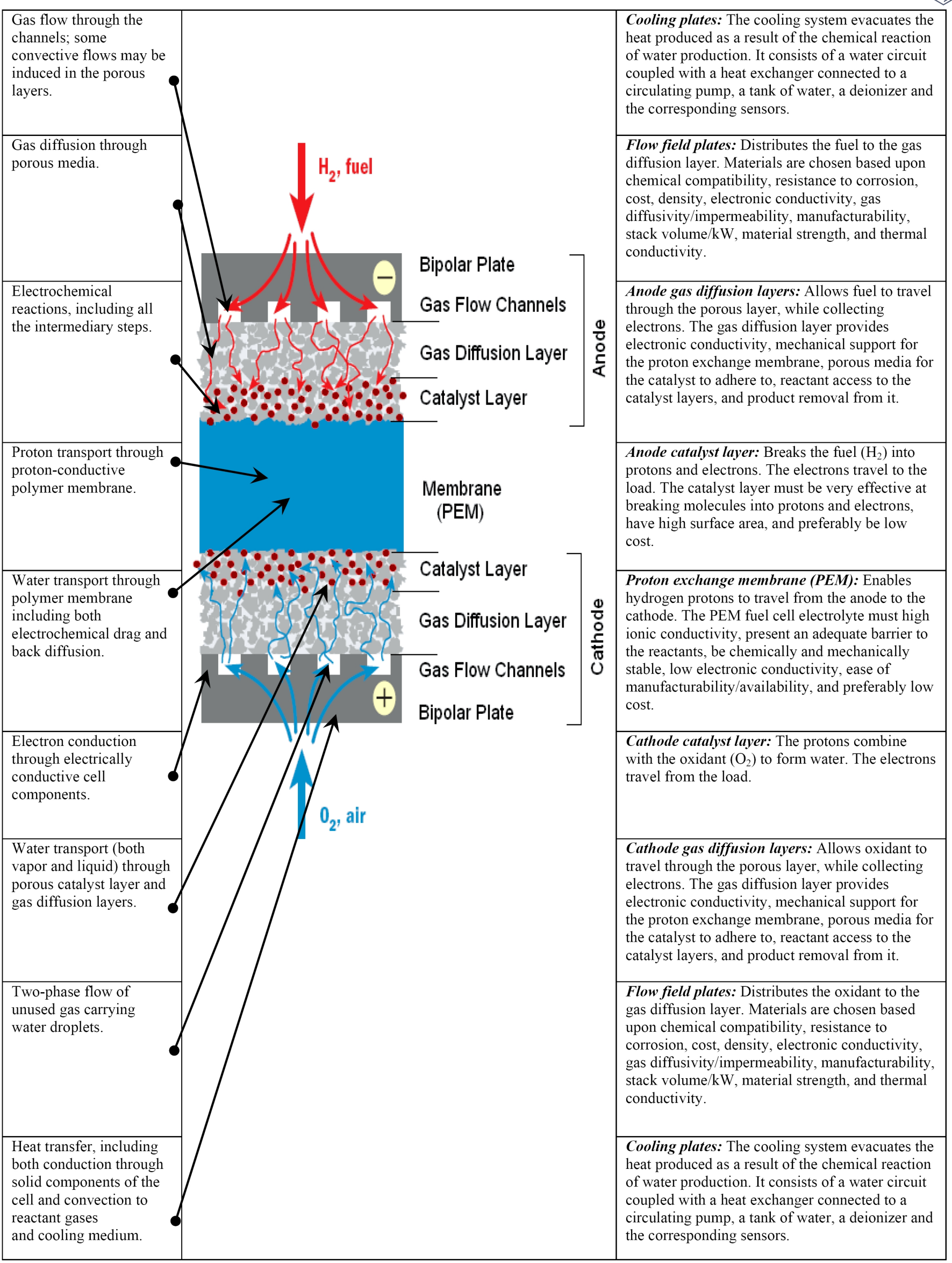

Figure 1. Main PEM fuel cell components and processes.

\section{CFD technology in developing PEM fuel cells}

\subsection{Understanding of transport phenomena in PEM fuel cells}


A comprehensive three-dimensional, multi-phase, non-isothermal model of a PEM fuel cell that incorporates the significant physical processes and the key parameters affecting fuel cell performance has been developed using CFD technology [5], [6] , [7], []. The model was developed to improve fundamental understanding of transport phenomena in PEM fuel cells and to investigate the impact of various operation parameters on performance. The model accounts for both gas and liquid phase in the same computational domain, and thus allows for the implementation of phase change inside the gas diffusion layers. The model includes the transport of gaseous species, liquid water, protons, energy, and water dissolved in the ion-conducting polymer. Water is assumed to be exchanged among three phases; liquid, vapor, and dissolved, and equilibrium among these phases is assumed. Water transport inside the porous gas diffusion layer and catalyst layer is described by two physical mechanisms: viscous drag and capillary pressure forces, and is described by advection within the gas channels. Water transport across the membrane is also described by two physical mechanisms: electro-osmotic drag and diffusion. The physics of phase change are included in this model by prescribing the local evaporation term as a function of the amount of liquid water present and the level of undersaturation, whereas the condensation has been a function of the level of oversaturation. The new feature of the algorithm developed in this model is its capability for accurate calculation of the local activation overpotentials, which in turn results in improved prediction of the local current density distribution. This CFD model also takes into account convection and diffusion of different species in the channels as well as in the porous gas diffusion layer, heat transfer in the solids as well as in the gases, and electrochemical reactions. The model reflects the influence of numerous parameters on fuel cell performance including geometry, materials, operating and others. The model is shown to be able to: understand the many interacting, complex electrochemical and transport phenomena that cannot be studied experimentally; identify limiting steps and components; and provide a computer-aided tool for design and optimization of future fuel cell with much higher power density and lower cost. In addition, the results show that the CFD model is capable of identifying important parameters for the wetting behavior of the gas diffusion layers and can be used to identify conditions that might lead to the onset of pore plugging, which has a detrimental effect of the fuel cell performance, especially in the mass transport limited region. Figure 2 shows some essential results of this CFD model $[\underline{5},[6],[7],[8]$. 

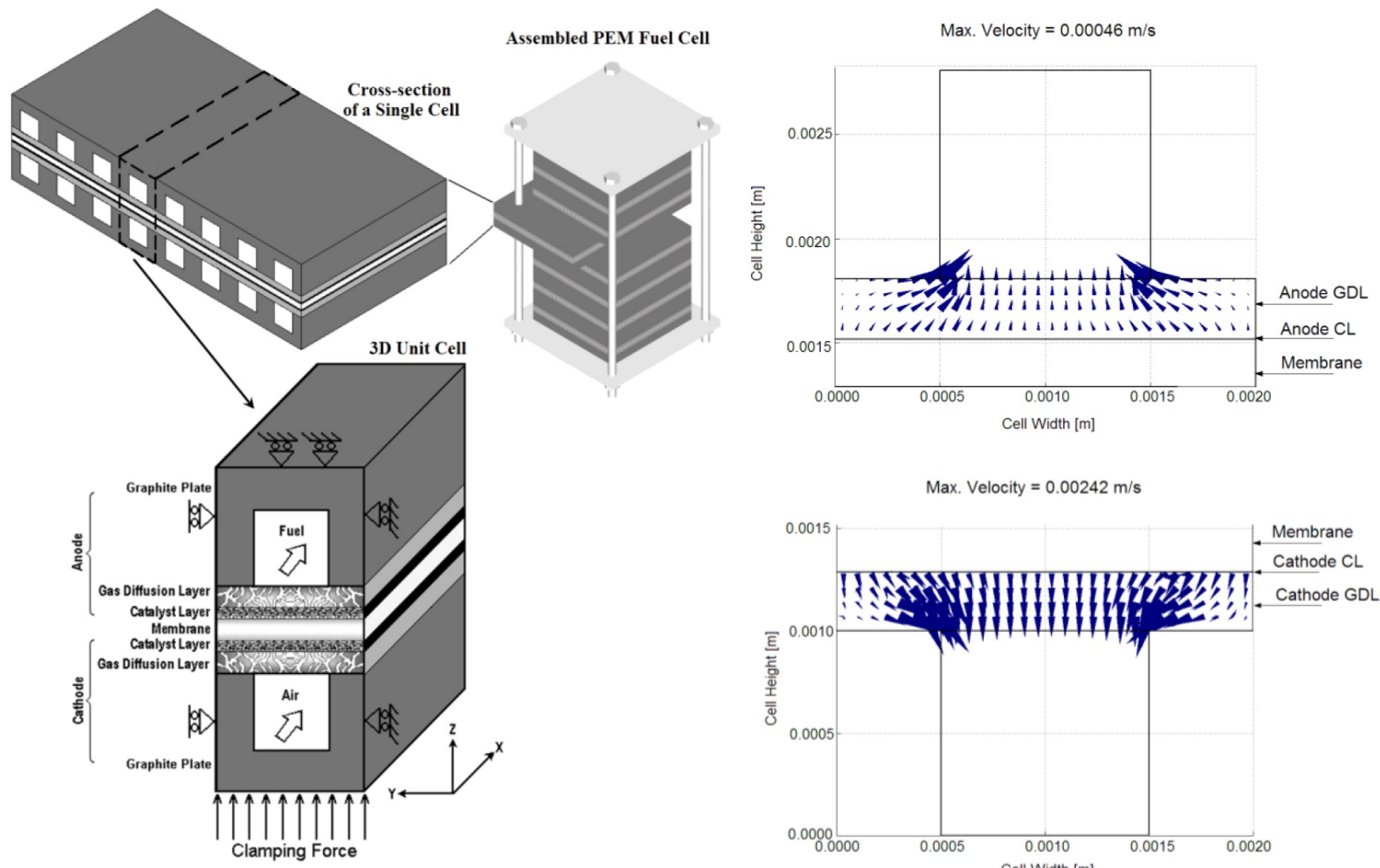

Three-dimensional computational domain
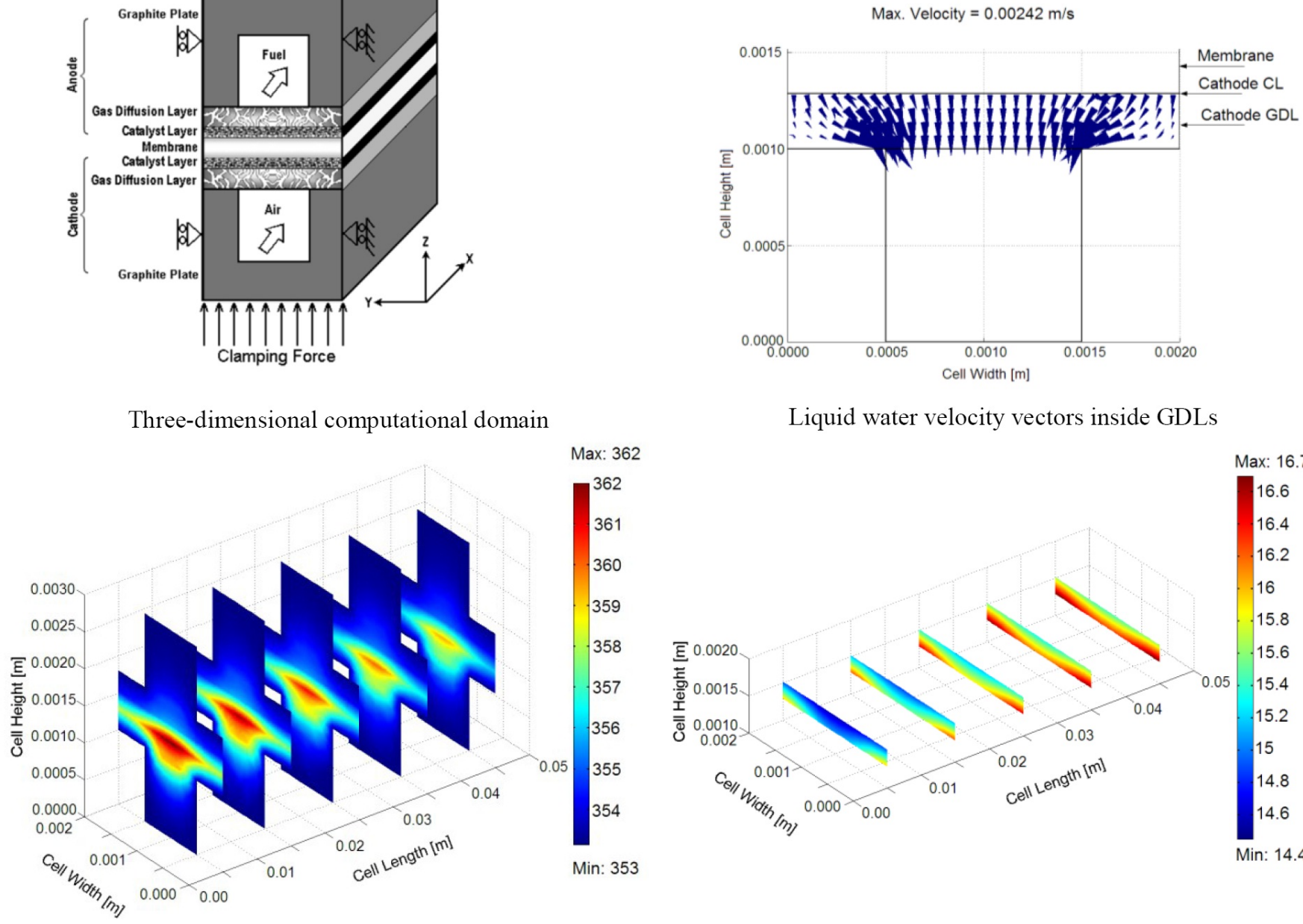

Liquid water velocity vectors inside GDLs

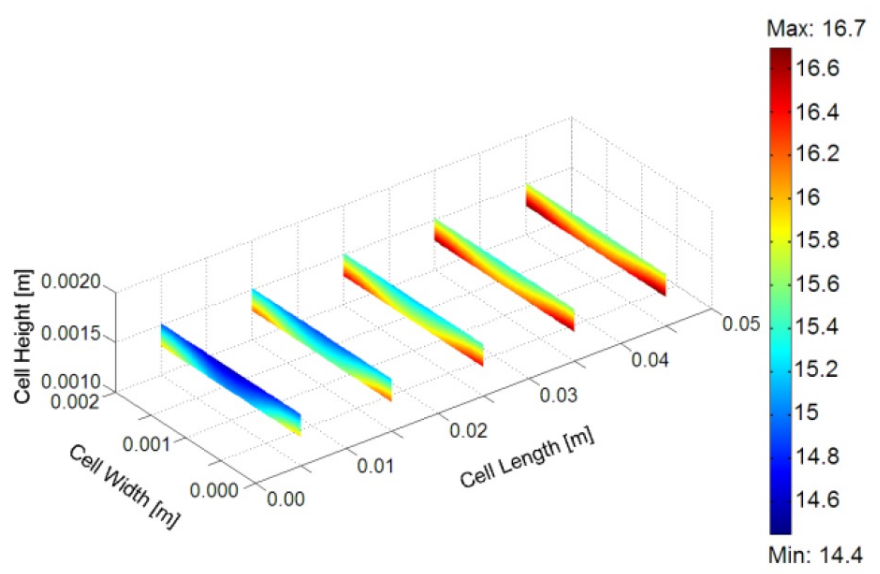

Temperature distribution inside the fuel cell

Water content profile through the membrane
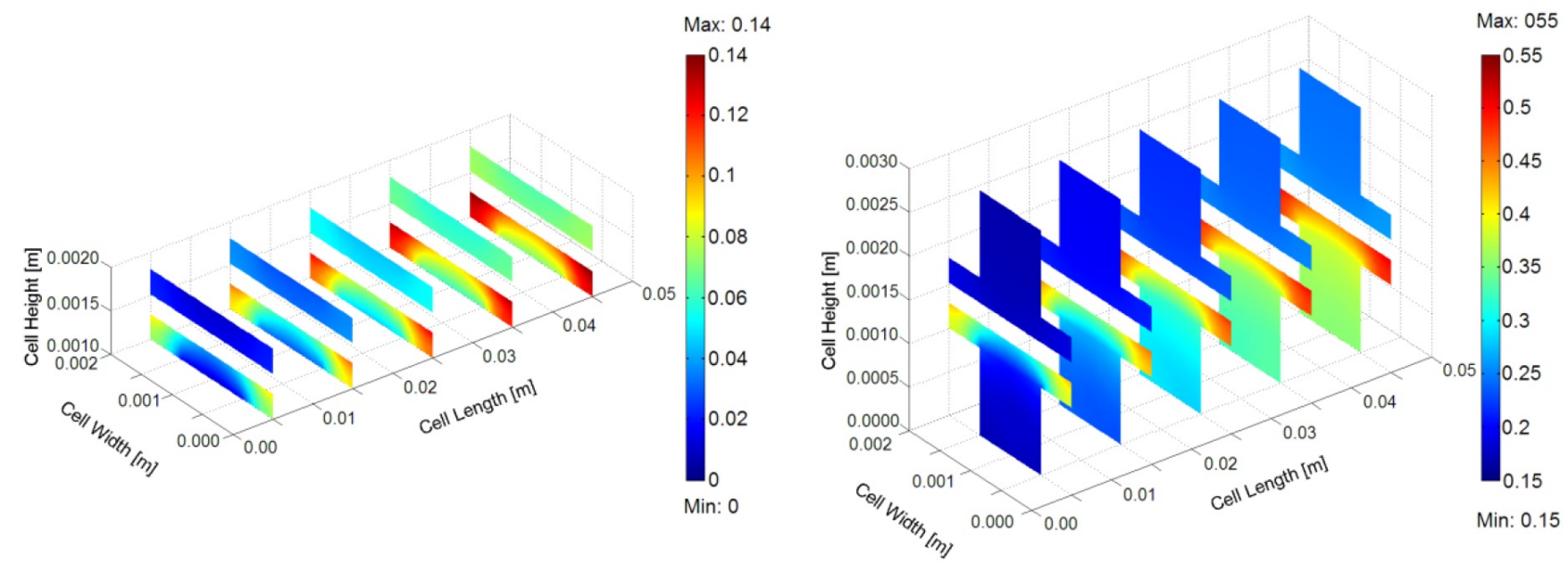

Liquid water saturation inside the GDLs

Water vapor molar fraction distribution in the cell 
Figure 2. Three Dimensional CFD modeling results of a PEM fuel cell[5]_[8].

\subsection{Design micro-scale PEM fuel cell}

Small fuel cells have provided significant advantages in portable electronic applications over conventional battery systems. Competitive costs, instant recharge, and high energy density make fuel cells ideal for supplanting batteries in portable electronic devices. Micro fuel cells belong to the category of portable fuel cells, but are used in the miniaturized electronic devices with low power, such as micro sensors. The presence of microelectromechanical system (MEMS) technology makes it possible to manufacture the miniaturized fuel cell systems for application in portable electronic devices. There are many new miniaturized applications which can only be realized if a higher energy density power source is available compared to button cells and other small batteries. Micro-fuel cells are considered as promising electrochemical power sources in portable electronic devices. The majority of research on micro-scale fuel cells is aimed at micro-power applications. Three-dimensional, non-isothermal CFD models for different designs of micro PEM fuel cells have been developed for the design and optimization of future micro fuel cells to improve their lifetime with a much higher power density and lower cost, [9], [10], [11], [12]. Figures 3-5 show CFD results for different new designs investigated for micro PEM fuel cells.
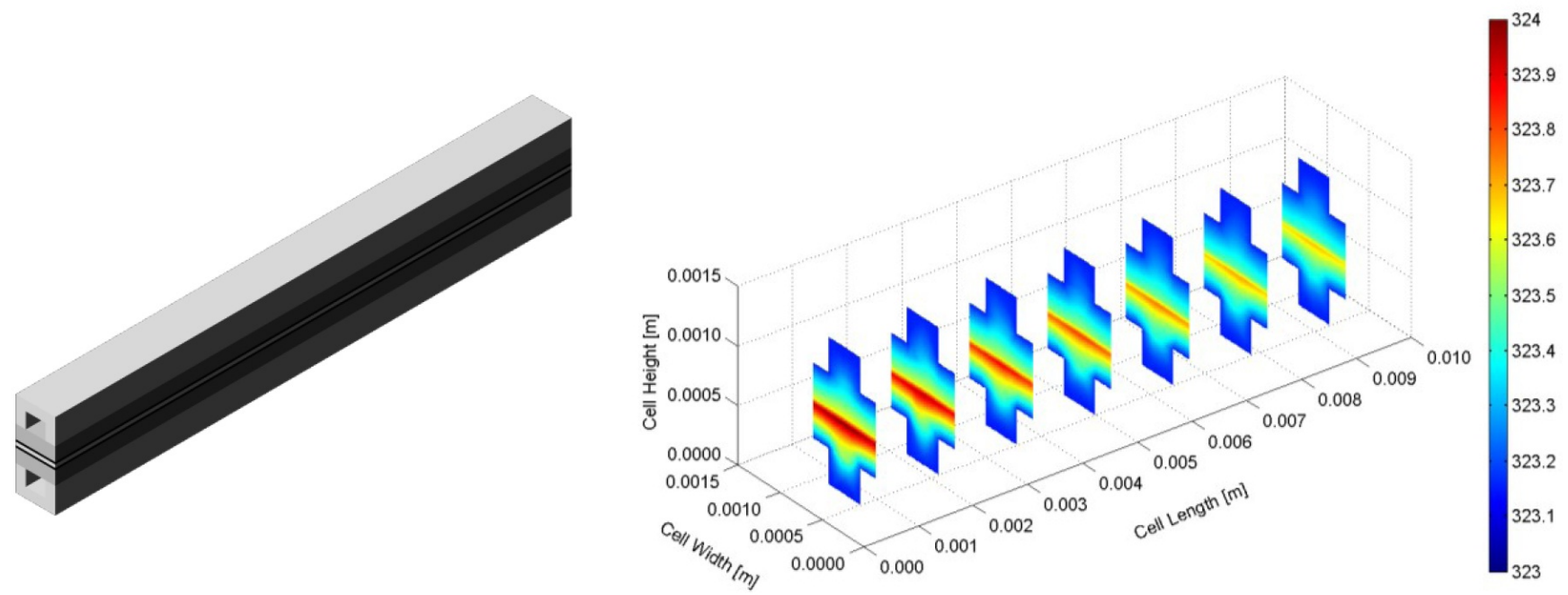

Figure 3. Three-dimensional computational domain and temperature distribution inside micro PEM fuel cell with straight gas flow channels ${ }^{[10]}$. 


\section{Encyclopedia}
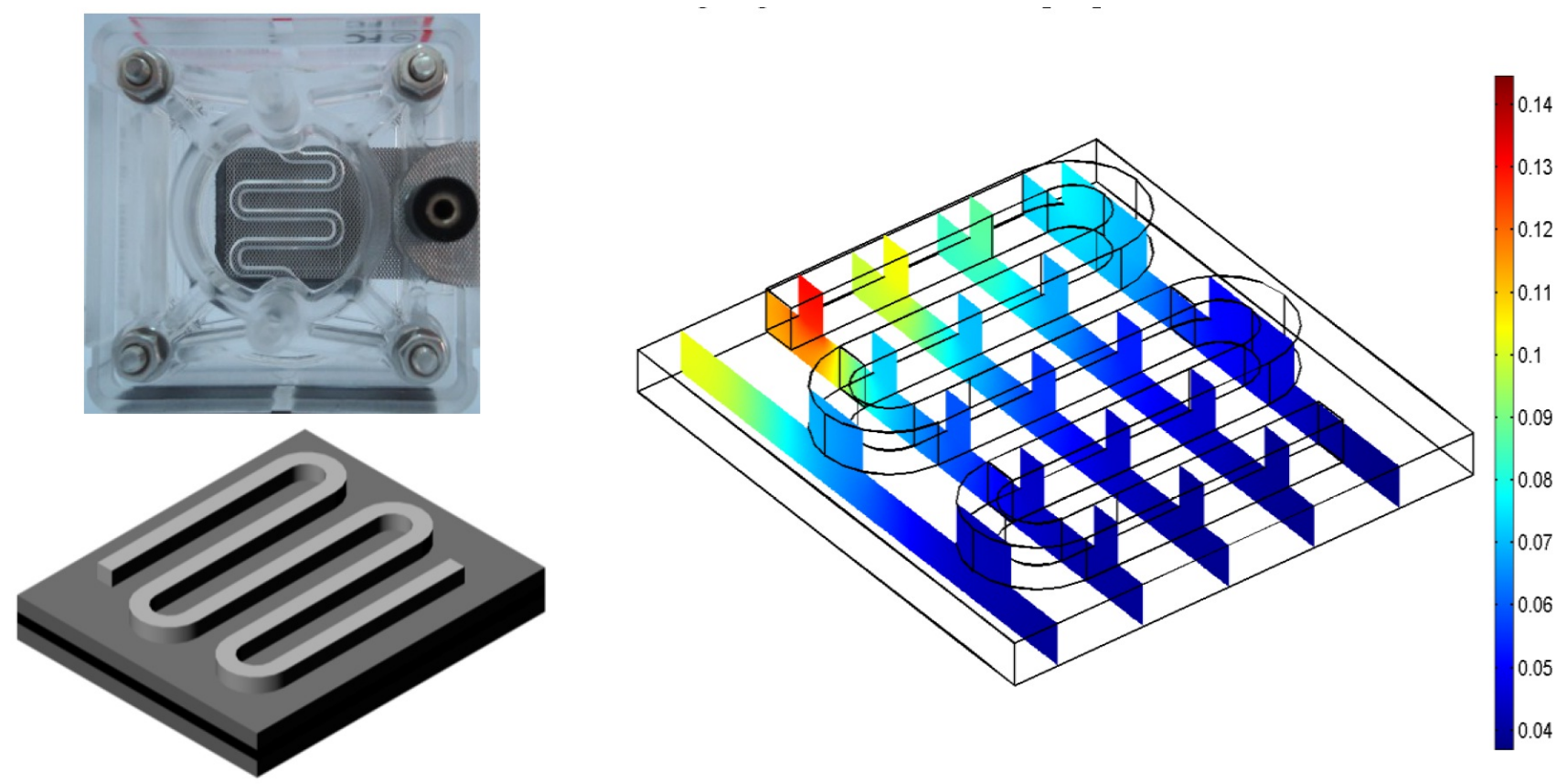

Figure 4. Three-dimensional computational domain and oxygen weight fraction distribution in micro PEM fuel cell with serpentine gas flow channels [11].
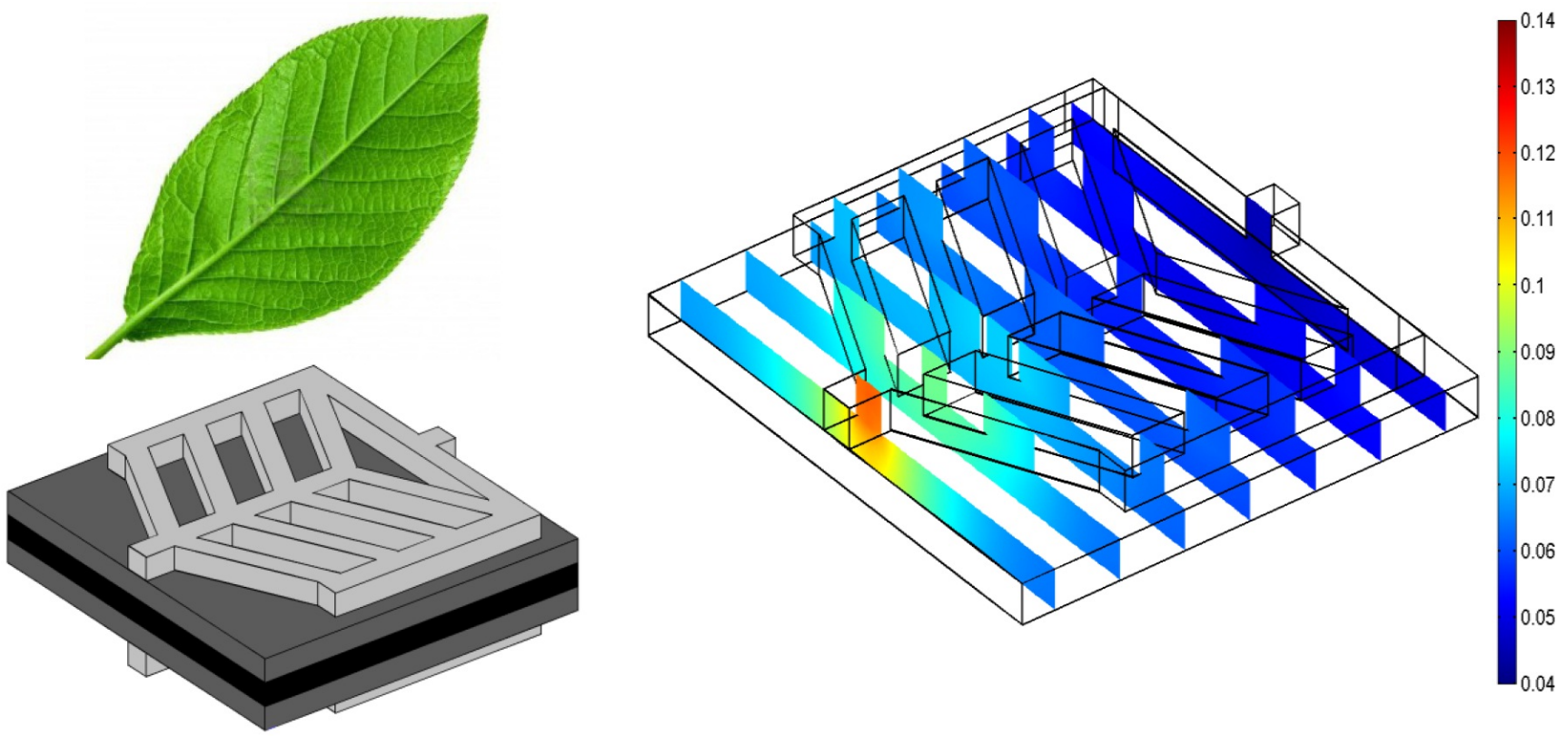

Figure 5. Three-dimensional computational domain and oxygen weight fraction distribution in micro PEM fuel cell with nature inspired gas flow channels. The design inspired from the existed biological fluid flow patterns in the leaf [12].

\subsection{Design air-breathing PEM fuel cell}

Although the small fuel cells have provided significant advantages in portable electronic applications over conventional battery systems. However, the typical PEM fuel cell system with its heavy reliance on subsystems for cooling, humidification and air supply would not be practical in small applications. The air-breathing PEM fuel cells without moving parts (external humidification instrument, fans or pumps) are one of the most competitive candidates for future portable-power applications. Three-dimensional, multi-phase, non-isothermal CFD models of different novel designs, simple to construct, PEM fuel cell which work in still or slowly moving air have been developed [13], [14], [15], [16], [17], [18], 
[19], [20], [21]. These novel geometries enable optimum air access to the cathode without the need for pumps, fans or similar devices. To the author's knowledge, these are the first novel designs. The results are presented and analyzed with a focus on the physical insight and fundamental understanding (see some examples in Figures 6 and 7). They can provide a solid basis for optimizing the geometry of the PEM fuel cell stack running with a passive mode.
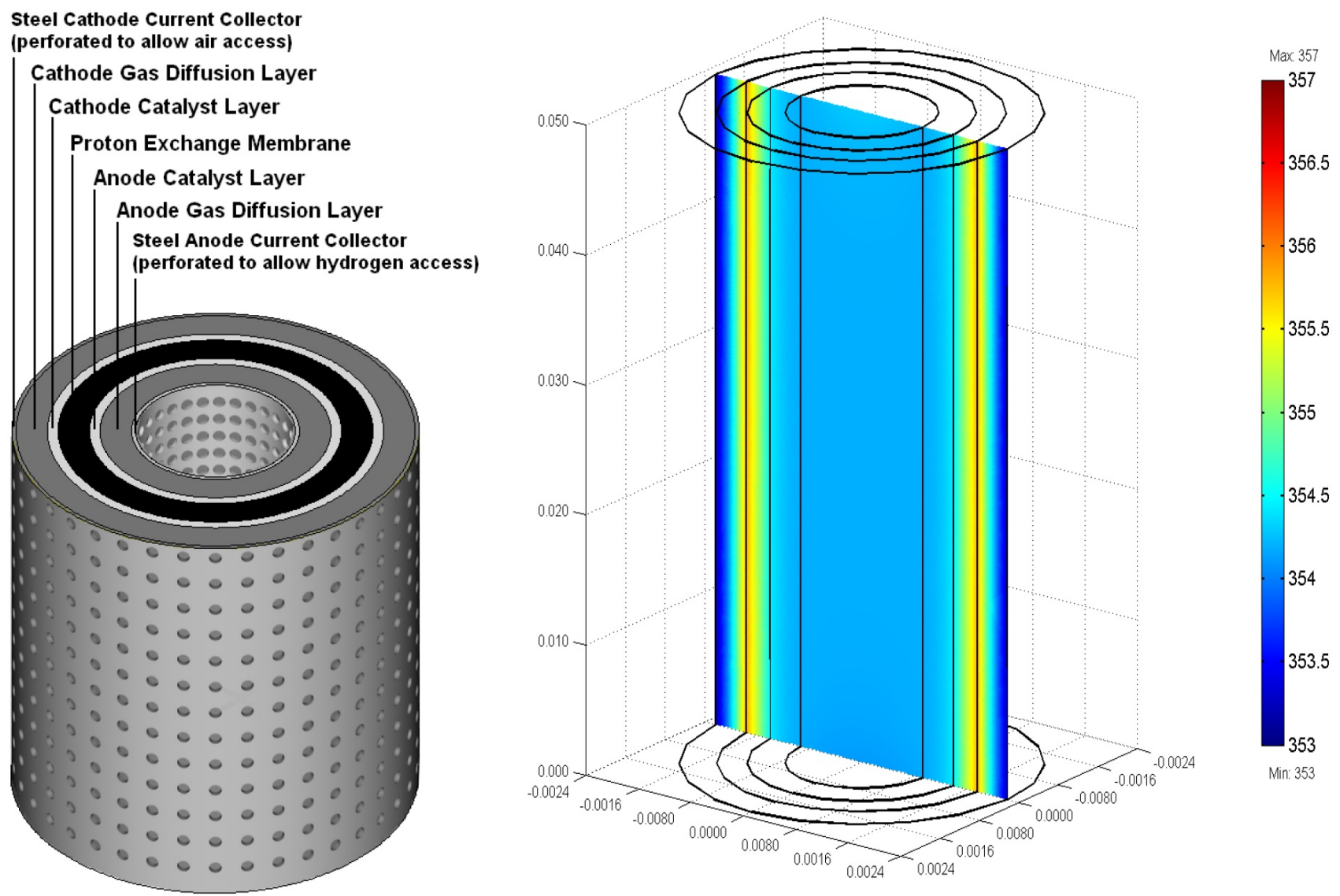

Figure 6. Three-dimensional computational domain of a tubular-shaped ambient air-breathing PEM fuel cell and the temperature distribution inside the cell at nominal current density of $1 \mathrm{~A} / \mathrm{cm} 2$ [13]_[17].
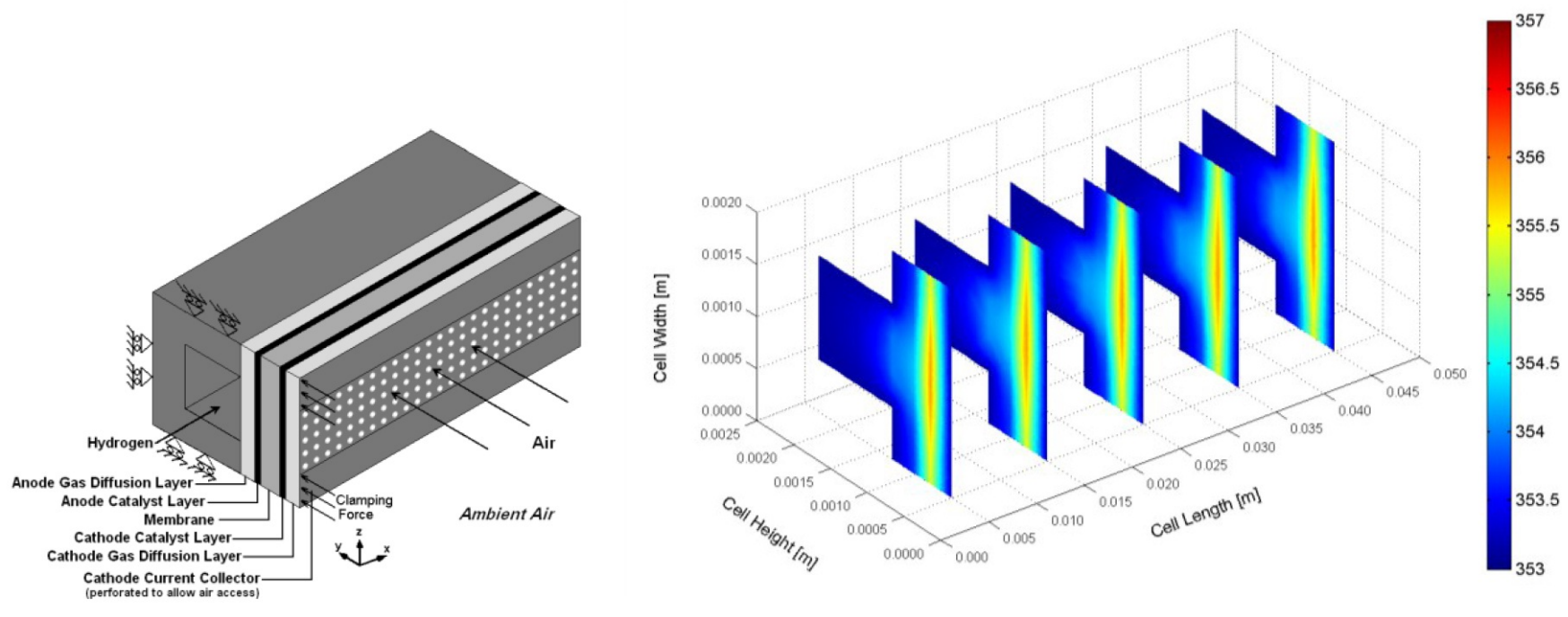

Figure 7. Three-dimensional computational domain of a planner ambient air-breathing PEM fuel cell and the temperature distribution inside the cell at nominal current density of $0.8 \mathrm{~A} / \mathrm{cm} 2$ [18]_[21] . 


\subsection{Design micro-air-breathing PEM fuel cell}

The appearance of portable microelectronic devices and off-the-grid sensors employed for biological, environmental and security monitoring leads to the high demand for miniaturized and reliable power sources. For such applications, having miniaturized high-energy-density power sources to provide long-term operation is a critical requirement. Micro air breathing fuel cell technology can take advantage of fuels with energy densities of an order of magnitude higher than the energy stored in batteries. To bring in the high energy density of fuels, the miniaturization and integration of fuel cell systems are inevitable.

Different novel geometries of air-breathing PEM micro fuel cell operating with hydrogen fed at the anode and air supplied by natural convection at the cathode have been designed using CFD technology [22], [23], [24], [25], [26]. There are several reasons that make these novel designs more advantageous than the usual one for medium to high power stacks: (i) elimination of the flow field: lower pressure drop at the anode fields and no time-consuming machinery due to shorter flow fields, (ii) uniform pressure applied to the MEA by the cathode, (iii) quicker response when switching from fuel cell mode to electrolyzer mode in a unitized regenerative fuel cell, (iv) greater cathode surface that increases the amount of oxygen reduction, the rate of which is slower than the hydrogen oxidation rate. In addition, (v) these designs can achieve much higher active area to volume ratios, and hence higher volumetric power densities.

A non-isothermal, fully three-dimensional CFD models of different novel designs for ambient air-breathing PEM micro fuel cell are presented with some examples in Figures 8-10. The informative results obtained can help in understanding of the local gas transports and electrochemical characteristics in air-breathing PEM micro fuel cells. Also, they can provide a solid basis for optimizing the geometry of the passive PEM micro fuel cell stacks. To the author's knowledge, these are the first new designs of air-breathing PEM micro fuel cells.
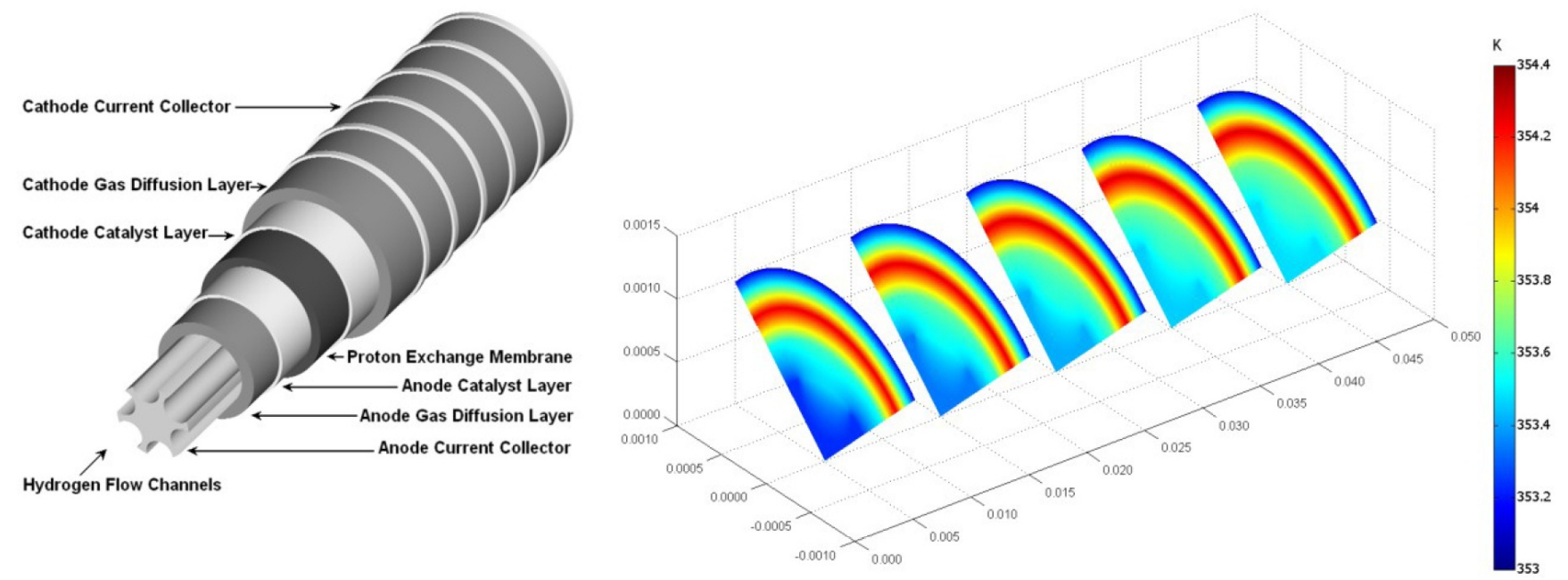

Figure 8. Three-dimensional computational domain of a tubular-shaped ambient air-breathing PEM micro fuel cell and the temperature distribution inside the cell 23$]$. 

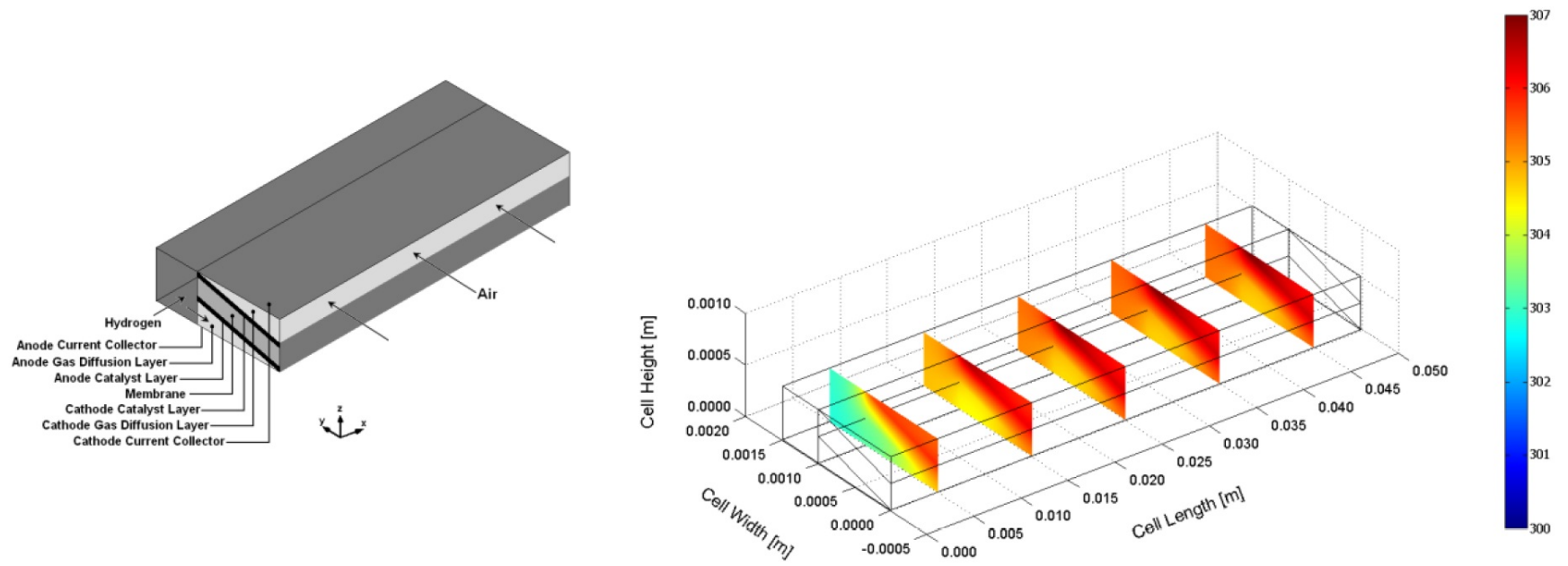

Figure 9. Three-dimensional computational domain of a planar compacted-design micro-structured ambient airbreathing PEM micro fuel cell and the temperature distribution inside the cell [24] , [25].
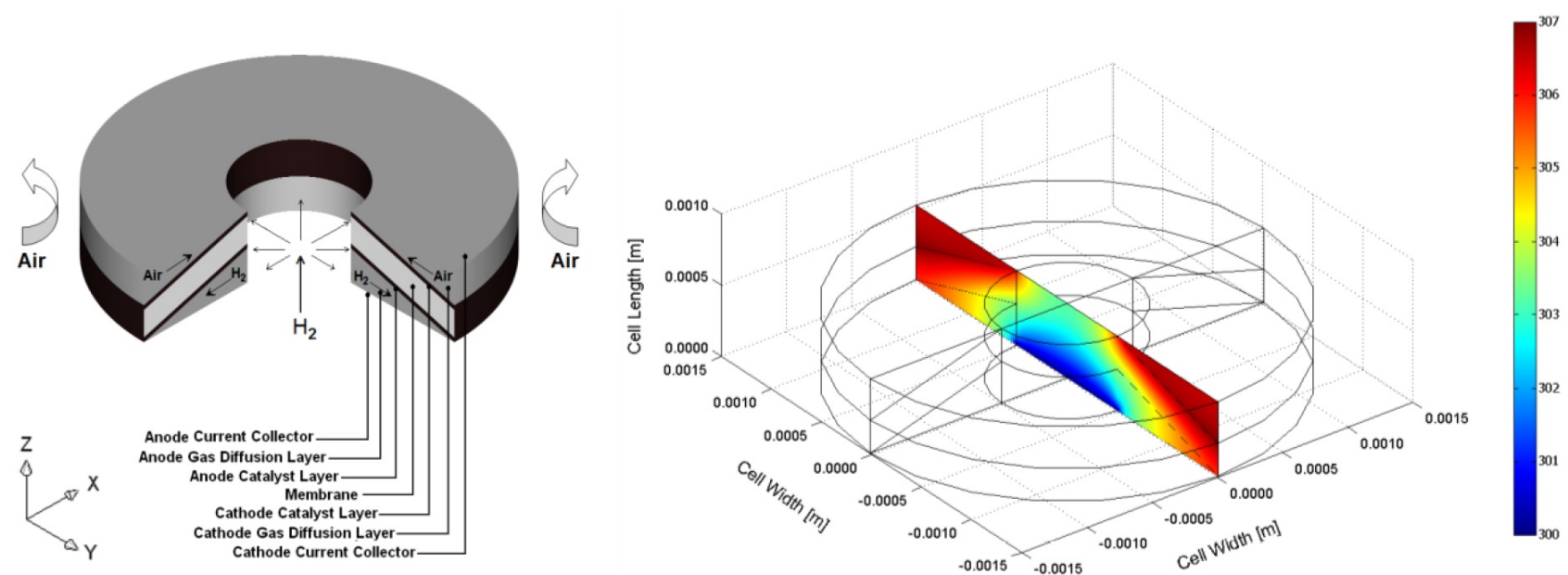

Figure 10. Three-dimensional computational domain of a disk-shaped micro-structured ambient air-breathing PEM micro fuel cell and the temperature distribution inside the cell [26].

\subsection{Understanding of mechanical and hygro-thermal stresses distribution inside PEM fuel cell}

The Membrane-Electrode-Assembly (MEA) is the core component of PEM fuel cell and consists of membrane with the gas-diffusion layers including the catalyst attached to each side. The fuel cell MEA durability plays a vital role in the overall lifetime achieved by a stack in field applications. Within the MEA's electrocatalyst layers are three critical interfaces that must remain properly intermingled for optimum MEA performance: platinum/carbon interface (for electron transport and catalyst support); platinum/Nafion interface (for proton transport); and Nafion/carbon interface (for high-activity catalyst dispersion and structural integrity).

The MEA performance shows degradation over operating time, which is dependent upon materials, fabrication and operating conditions. Mechanical degradation is often the cause of early life failures. Mechanical stresses which limit MEA durability have two origins. Firstly, this is the stresses arising during fuel cell assembly (bolt assembling). The 
bolts provide the tightness and the electrical conductivity between the contact elements. Secondly, additional mechanical stresses occur during fuel cell running because PEM fuel cell components have different thermal expansion and swelling coefficients. Thermal and humidity gradients in the fuel cell produce dilatations obstructed by tightening of the screw-bolts. Compressive stress increasing with the hygro-thermal loading can exceed the yield strength which causes the plastic deformation. The mechanical behavior of the membrane depends strongly on hydration and temperature.

An operating fuel cell has varying local conditions of temperature, humidity. As a result of in the changes in temperature and moisture, the membrane, GDL and bipolar plates will all experience expansion and contraction. Because of the different thermal expansion and swelling coefficients between these materials, hygro-thermal stresses are introduced into the unit cell during operation. In addition, the non-uniform current and reactant flow distributions in the cell result in non-uniform temperature and moisture content of the cell which could in turn, potentially causing localized increases in the stress magnitudes, and this leads to mechanical damage, which can appear as through-thethickness flaws or pinholes in the membrane, or delaminating between the polymer membrane and gas diffusion layers. Therefore, in order to acquire a complete understanding of these damage mechanisms in the membranes and the gas diffusion layers, mechanical response under steady-state hygro-thermal stresses should be studied under real cell operation conditions.

Three-dimensional CFD models of a PEM fuel cell have been developed to simulate and analyze the stresses distribution and deformation inside the cell, which are occurring during fuel cell assembly (bolt assembling), and membrane swelling and cell materials expansion during fuel cell running due to the changes of temperature and relative humidity [27], [28], [29], [30], [31], [32]. To the author's knowledge, Maher A.R. Sadiq Al-Baghdadi's works[27], [28], [29], [30], [31], [32] are the first to incorporate the effect of mechanical and hygro-thermal stresses into actual fuel cell model with three-dimensional effect using CFD technology. The behavior of the whole cell during operation has been studied and investigated under real cell operating conditions. The results show that the non-uniform distribution of stresses, caused by the temperature and relative humidity gradient in the cell, induces localized bending stresses, which can contribute to delaminating between the membrane and the gas diffusion layers. These stresses may explain the occurrence of cracks and pinholes in the membrane under steady-state loading during regular cell operation. Figure 11 shows stress distribution and total displacement inside the PEM fuel cell during operation. To the author's knowledge, this has not been specifically described before. 


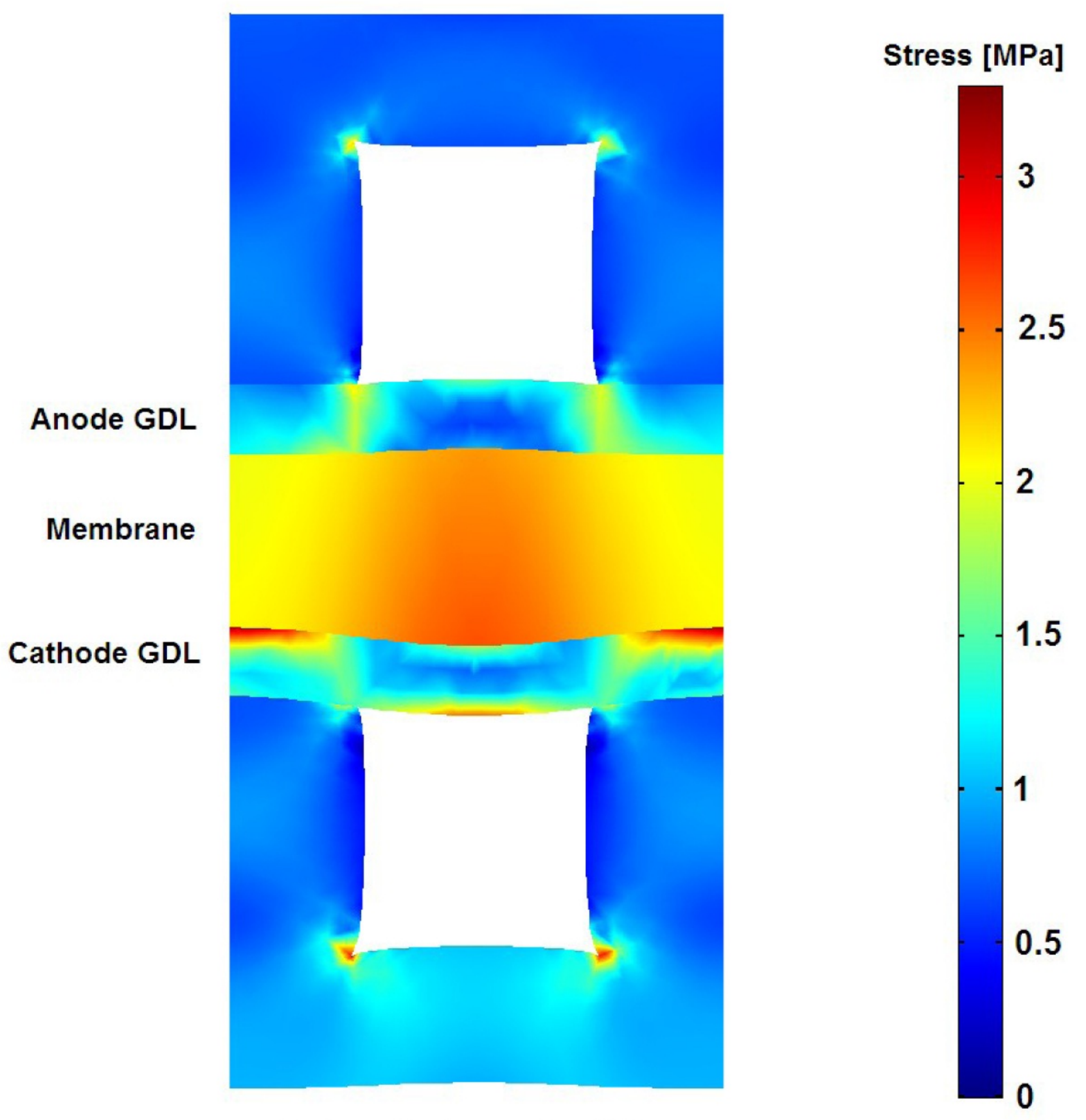

Maximum Displacement $=2.78 \mu \mathrm{m}$

Figure 11. von Mises stress distribution inside the cell (contour) and total displacement (deformed shape plot, scale enlarged 200 times) on the $y-z$ plane at $x=10 \mathrm{~mm}$ [27].

\subsection{Changes of the physical properties for the cell components during fuel cell work}

PEM fuel cell assembly pressure is known to cause large strains in the cell components. All components compression occurs during the assembly process of the cell, but also during fuel cell operation due to membrane swelling when absorbs water and cell materials expansion due to heat generating in catalyst layers. Additionally, the repetitive channel-rib pattern of the bipolar plates results in a highly inhomogeneous compressive load, so that while large strains are produced under the rib, the region under the channels remains approximately at its initial uncompressed state. This leads to significant spatial variations in GDL thickness and porosity distributions, as well as in electrical and thermal bulk conductivities and contact resistances (both at the ribe-GDL and membrane-GDL interfaces). These changes affect the rates of mass, charge, and heat transport through the GDL, thus impacting fuel cell performance and lifetime. 
Figure 12 illustrates the CFD results of the changes suffered by the porosity field during the compression process as a result of assembly process of the stack, and also as a result of membrane swelling, and cell materials expansion due to the temperature and relative humidity cycles during operation [33]. The GDL intrusion into the channel and the compressive stress applied at the rib symmetry plane are also indicated for illustrative purposes. The inhomogeneity associated with the repetitive channel-rib pattern is perfectly reflected, showing a region of large porosity reduction under the rib, a region of unperturbed porosity under the channel, and an intermediate fan like transition region below the channel-rib wall. Note in particular the accumulation of stresses under the rib corner, which results in high porosity reduction in this particular region. The simulations also show that the upper edge of the GDL experiences slight tensile strains in the region below the channel, thereby increasing the GDL porosity above its initial value 0.4.

In a real PEM fuel cell stack, the contact pressure on the GDL is different from the clamping pressure because of the channels in the bipolar plate. Furthermore, due to the round corners of the bipolar plate, the contact behavior at the interface is hard to predict without a CFD analysis. Figure 13 shows the interfacial contact resistance along the rib width.

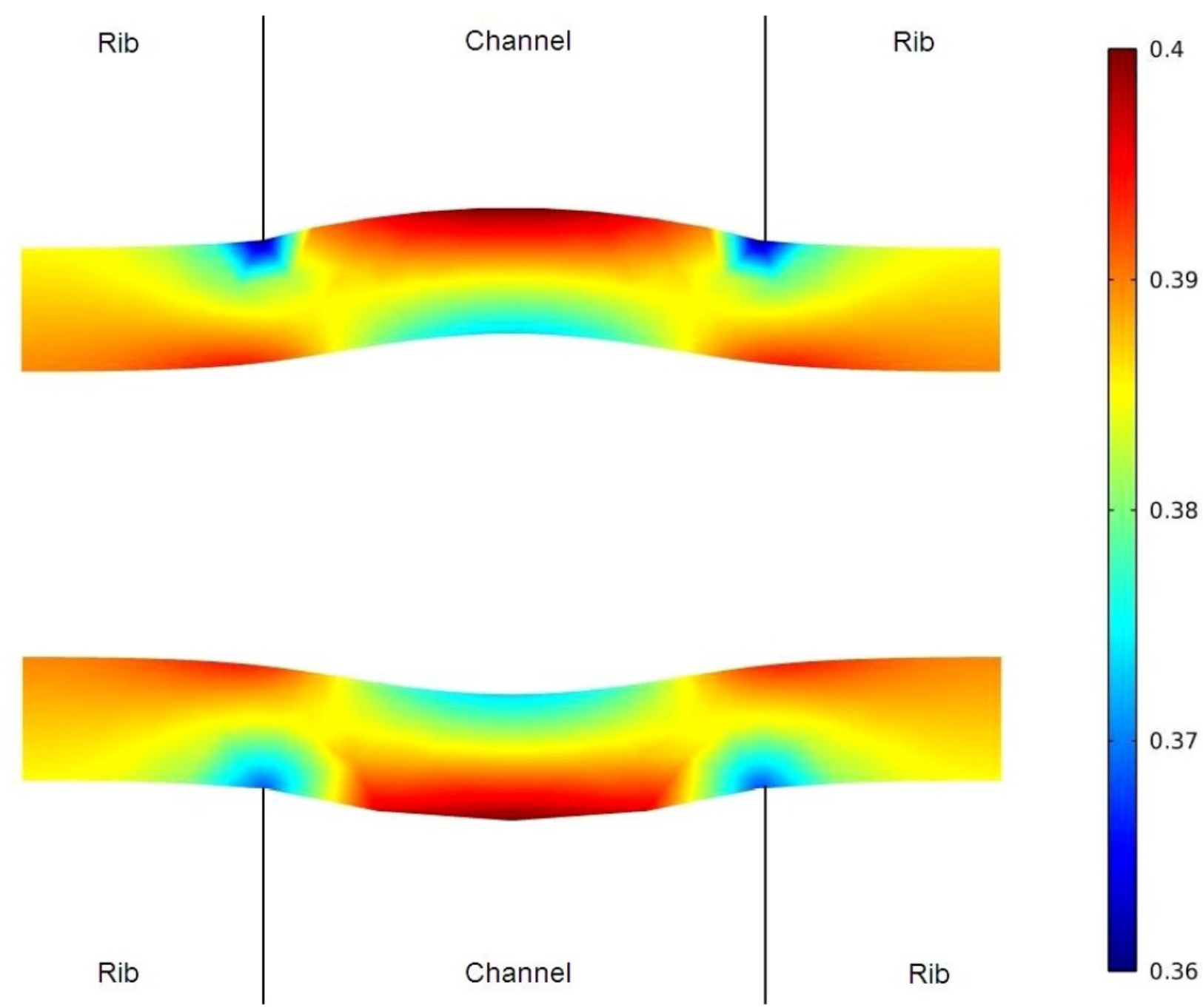

Figure 12. Porosity distribution in the GDLs (contour) and total displacement (deformed shape plot, scale enlarged 250 times) on the $y-z$ plane at $x=10 \mathrm{~mm}[\underline{33}$. 


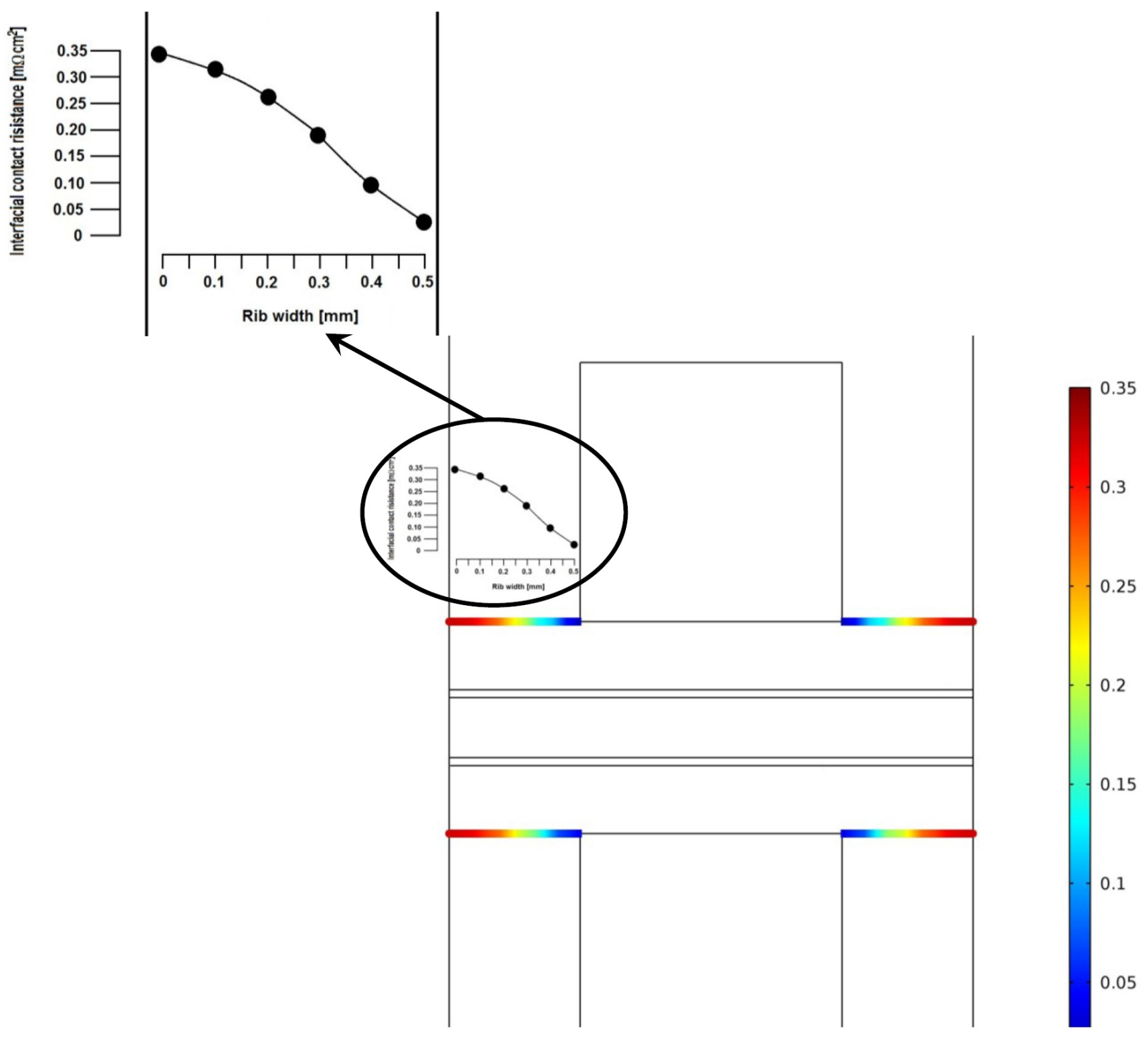

Figure 13. Interfacial contact resistance GDL/bipolar plate a long the rib width ${ }^{[33]}$.

\subsection{Optimization of PEM fuel cell performance}

A parametric study using three-dimensional, multi-phase nonisothermal model of a PEM fuel cell has been performed using CFD simulation. A detailed analysis of the fuel cell performance under various operating conditions has been conducted and the effects of operating, design, and material parameters have been examined [34], [35], [36], [37], [38], [39]. The analysis helped identifying critical parameters and shed insight into the physical mechanisms leading to a fuel cell performance under various conditions. Optimization study of a PEM fuel cell performance has been performed. The study quantifies and analyses the impact of operating, design, and material parameters on fuel cell performance and get an optimal conditions for PEM fuel cells to generate maximum power and also to achieve long cell life. To the author's knowledge, this has not been specifically studied before. Figure 14 shows some delightful results when using CFD technology in optimization study of PEM fuel cell. 

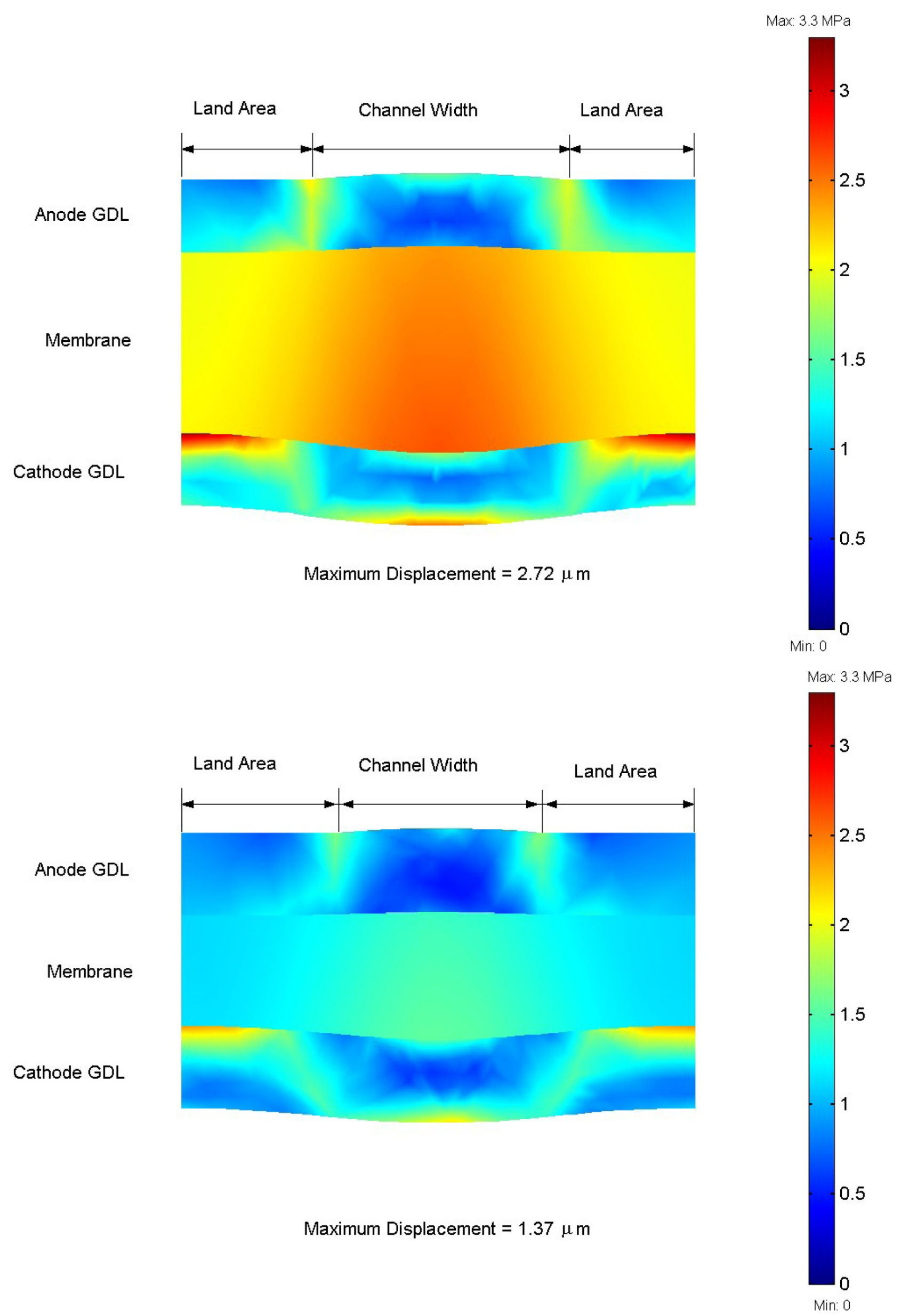

Figure 14. Mises stress distribution (contour) and total displacement (deformed shape plot, X200) in the MEA: at base case conditions (upper), and for optimum design, material, and operating conditions (lower) ${ }^{[35]}$. 


\subsection{Understanding of pressure distribution inside a running PEM fuel cell stack}

The fuel cell stack is sized to generate the designed power output. PEM fuel cells show some losses of efficiency and power density with the scale up when the number of cells and their areas increase in a stack. As fuel cell manufacturing scales up, the relationship between fuel cell performance and design, manufacturing, and assembly processes must be well understood. The PEM fuel cell stack is a sandwich-like structure composed of many layers, materials and interfaces. The pressure distribution in PEM fuel cell stack therefore is affected by the component material properties, geometrical parameters and the clamping method. Assembly pressure plays a significant role in determining fuel cell performance [40] , [41]. During the assembly of a PEM fuel cell stack, GDL, bipolar plate, and membrane are clamped together using mechanical devices. A proper level of clamping pressure is needed to provide adequate gas sealing, as well as to reduce contact resistances at component interfaces. However, too high a pressure may over-compress the membrane and GDL, crushing their porous structures and cracking the bipolar plate. In addition, the electrical contact resistance, which constitutes a significant part of the ohmic resistance in a cell, especially when stainless steel, titanium or molded graphite is chosen as the bipolar plate material, can be significantly altered by clamping pressure and operating conditions. Assembly pressure makes the part of GDL under the land area be compressed and the part under channel area be protruded into channel cavity. This inhomogeneous compression causes unevenness of the material properties of GDL. The inhomogeneous deformation of GDL as well as significant change of material properties influences fuel cell performance and durability dramatically.

PEM fuel cell stack assembly process, including clamping pressure, material properties of each component, design (component thickness and cell active area), and number of cells in the stack are important factors influencing the performance and durability of the PEM fuel cell stack. Furthermore, when temperature and relative humidity increase during operation, the membrane absorbs water and swells. Since the relative position between the top and bottom end plates is fixed, the polymer membrane is spatially confined. Thus the GDL will be further compressed under the land and the intrusion into channel becomes more significant. Assembly pressure, contact resistance, membrane swelling and operating conditions, etc., combine to yield an optimum assembly pressure.

Variations in temperature and humidity during operation cause stresses and strains (mechanical loading) in the membrane as well as in all components and are considered to be the mechanical failure driving force in fuel cell applications. Investigating the mechanical response of the PEM fuel cell stack during operation (subjected to change in humidity and temperature) requires studying and modeling of the stress-strain behavior of all fuel cell stack components in operation phase.

The use of the CFD technology allows the study of the physical phenomenon within a fuel cell stack such as heat and energy transport as well as the pressure distribution inside all components of the stack without the need to build a structure, eliminating the manufacture and machining costs. The 3D CFD model enables the prediction of the distribution and visualization of various parameters influencing the stack behavior. Figure 15-17 show specific results from the study of the pressure effects by combining the mechanical and electrochemical phenomena in PEM fuel cells stack [40], [41]. 


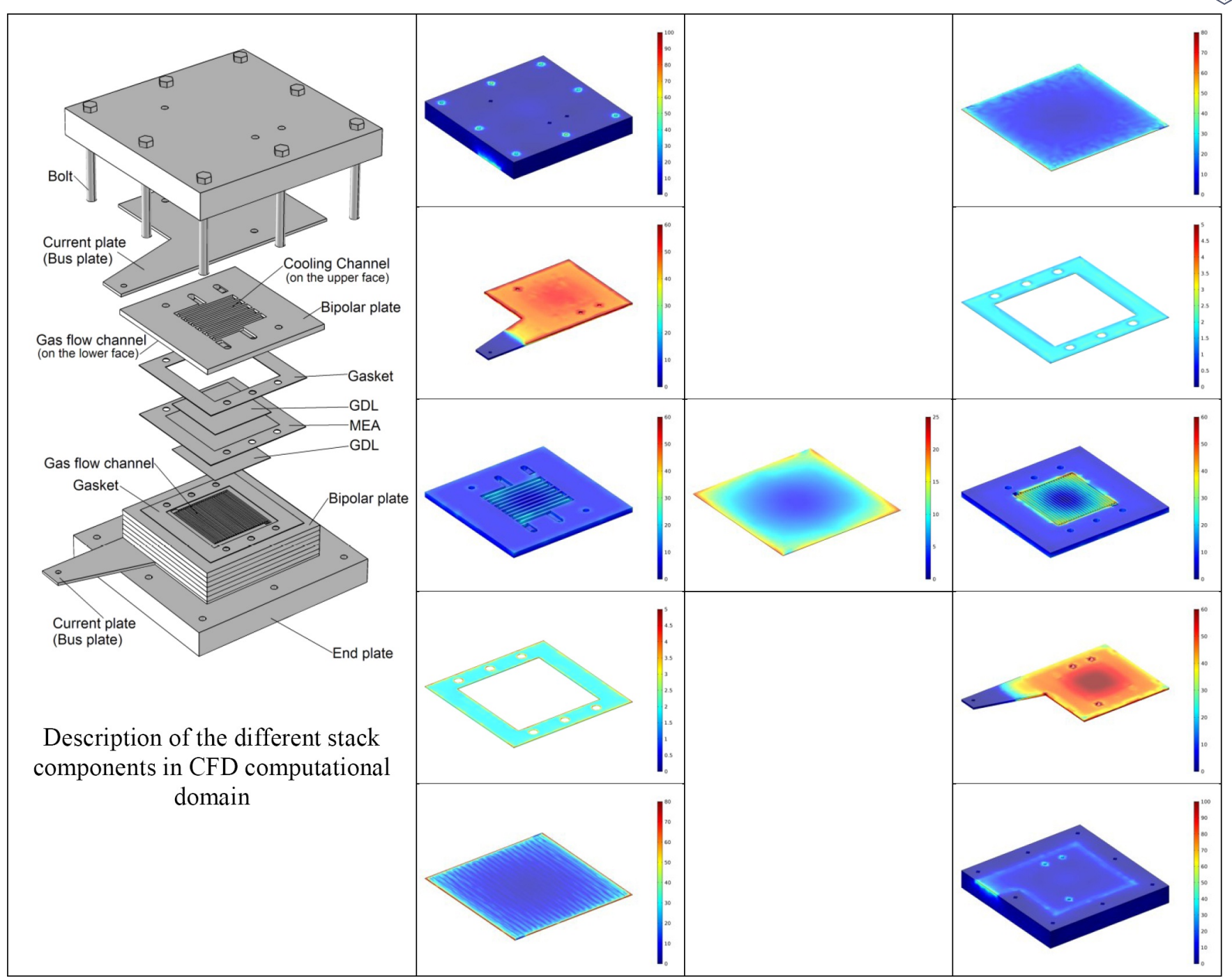

Figure 15. von Mises stress distribution in the single-cell stack components during operation [MPa], [40, 41].
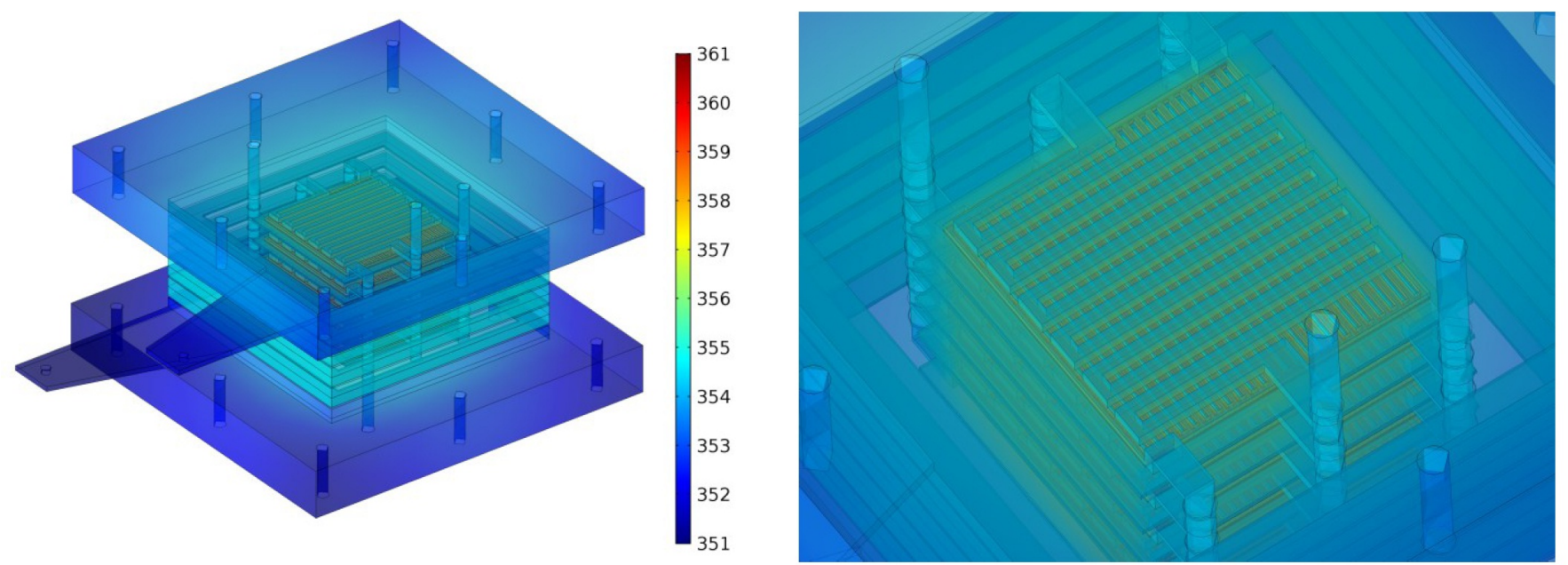

Figure 16. Solid-phase temperature distribution in the five-cell stack components during operation $[\mathrm{K}], \frac{[40]}{, 441]}$. 


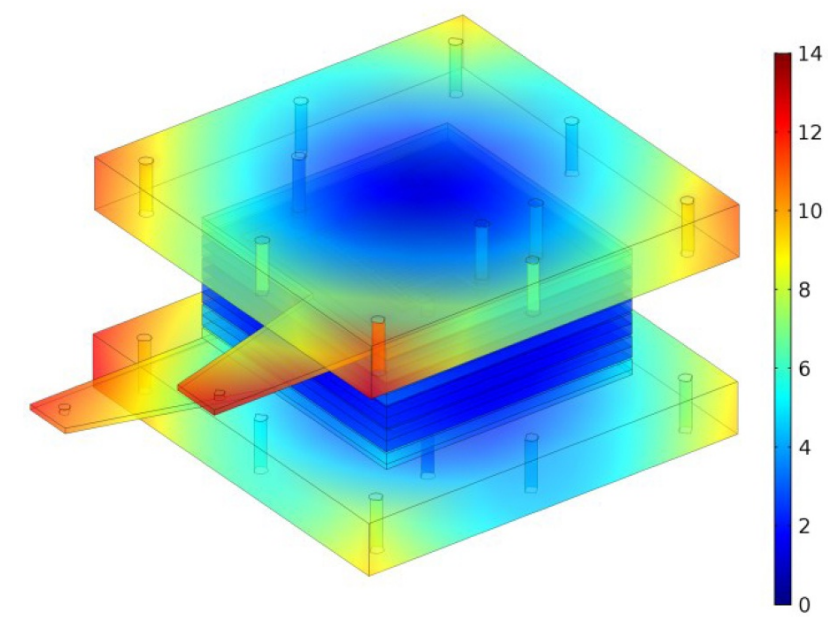

During assembly process.

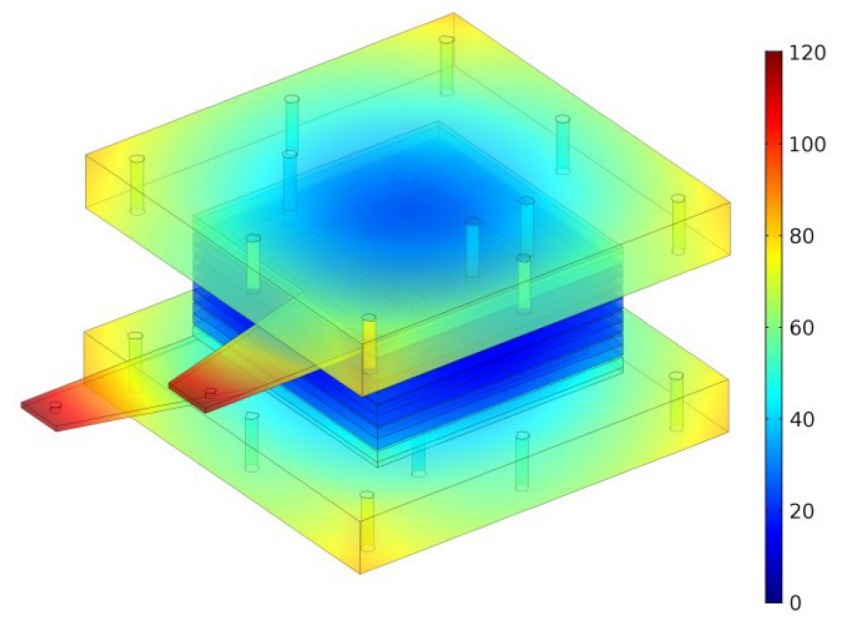

During operation.

Figure 17. Total displacement distribution in the five-cell stack components $[\mu \mathrm{m}],[40],[41]$.

\subsection{Natural vibration and mode shapes of PEM fuel cell stack}

A PEM fuel cell stack is laminated with a number of plate-type cells, and the latest model is assembled by compression from both ends of plates. PEM fuel cells are exposed to high magnitude vibrations, shocks, and cyclic loads in many applications. Vibrations during operation show significant impact in the longer run of the fuel cells. Frequencies which are not close to the resonant frequencies or natural frequencies show very little effect on the overall performance. However, if the frequency ranges of operation approaches the resonant frequency range, the probability of component failure increases. It is possible that there will be lateral transition of cells or leakage of fuel gas and coolant water. Therefore, it is necessary to evaluate the effects vibration has on the fuel cell.

Vibration characteristics are required to understand the vibration behavior of PEM fuel cell stack components such as the membrane, catalyst layer, gas diffusion layers, bi-polar plates, gasket, current plates, and end plates. Vibrating at resonance frequency can lead to the initiation and acceleration of defect formation, which may ultimately result in operational failure. Vibrations may exacerbate defects such as pinholes, cracks, and delamination, which can result in fuel crossover, leakage of fuel gas and coolant water, performance degradation, and reduced durability.

Natural frequencies and mode shapes of the PEM fuel cell stack has been modeled using CFD methodologies. The work aims to understand the vibration characteristics of a PEM fuel cell stack and to evaluate their seismic resistance under a vibration environment. A parametric study has been conducted to investigate how the natural frequency varies as a function of thickness, Young's modulus, and density for each component layer. In addition, this work provides insight into how the natural frequencies of the PEM fuel cell stack should be tuned to avoid high amplitude vibrations by modifying the material and geometric properties of individual components [42]. The mode shapes of the PEM fuel cell stack provide insight into the maximum displacement exhibited under vibration conditions that should be considered for transportation and stationary applications. Figure 18 shows some wonderful results of this CFD model. 


\section{Encyclopedia}

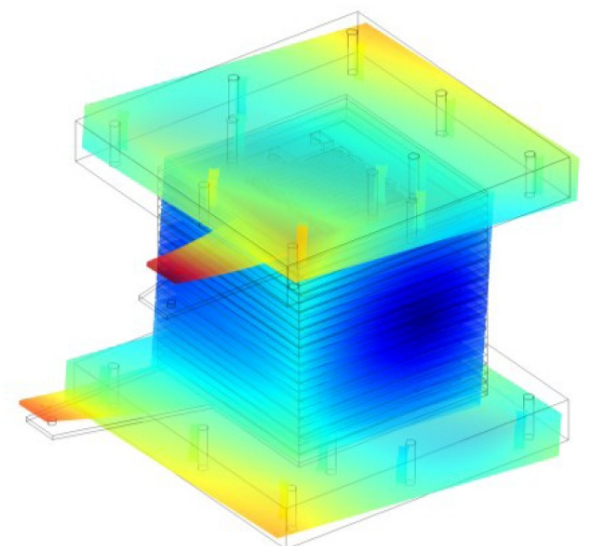

Mode 1, frequency $393.31 \mathrm{~Hz}$.

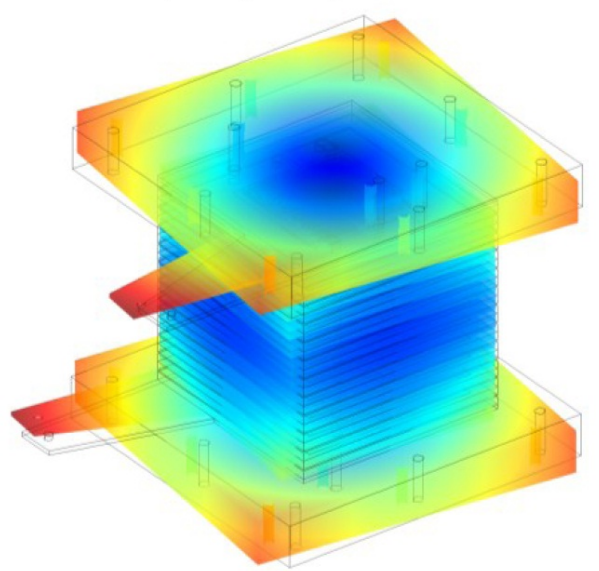

Mode 3, frequency $471.46 \mathrm{~Hz}$.

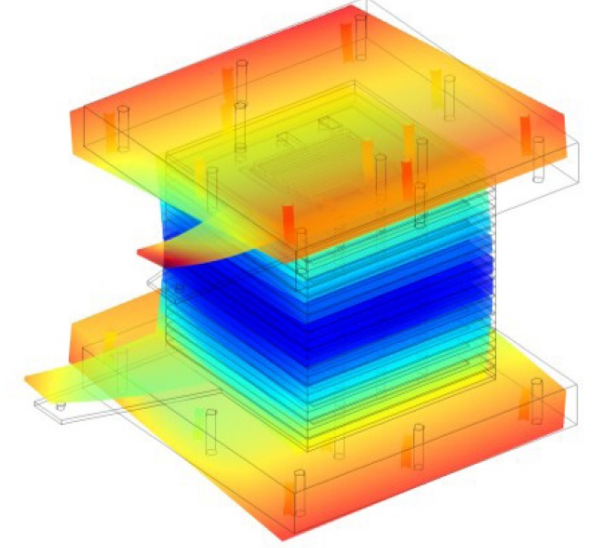

Mode 5, frequency $721.37 \mathrm{~Hz}$.

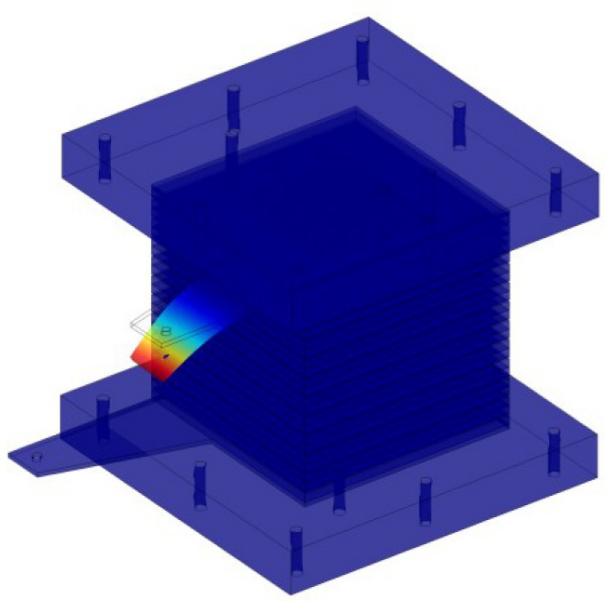

Mode 7, frequency $1102.3 \mathrm{~Hz}$.

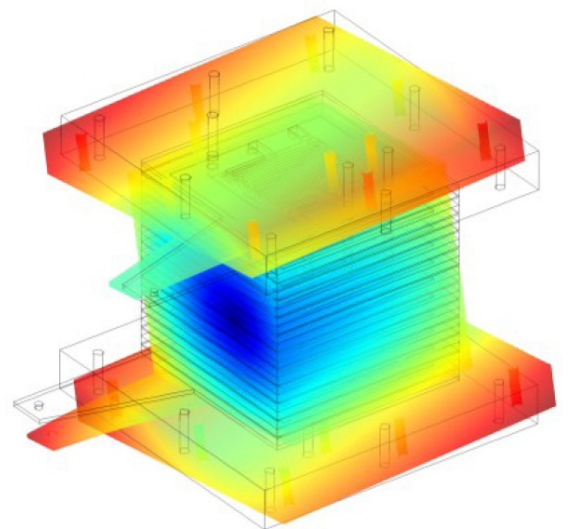

Mode 2, frequency $400.01 \mathrm{~Hz}$.

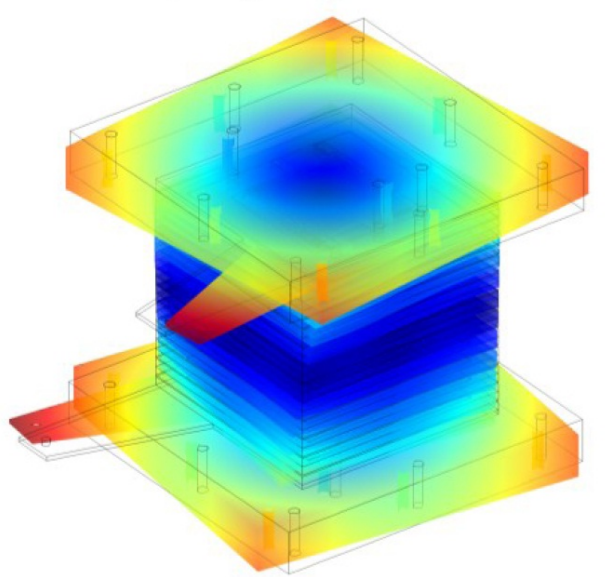

Mode 4, frequency $612.41 \mathrm{~Hz}$.

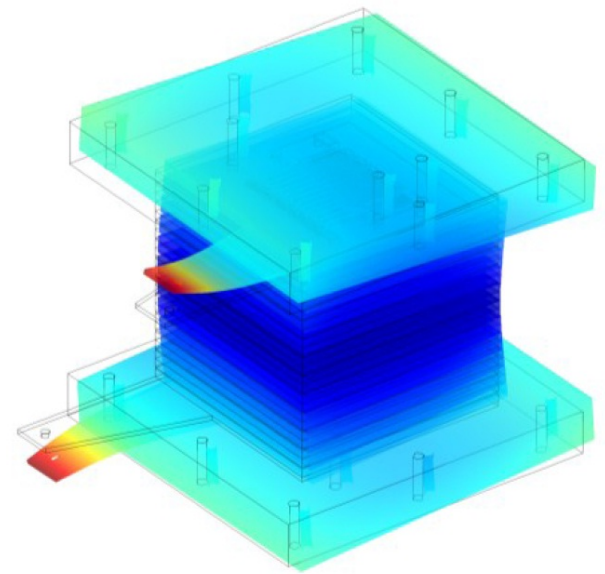

Mode 6, frequency $724.88 \mathrm{~Hz}$.

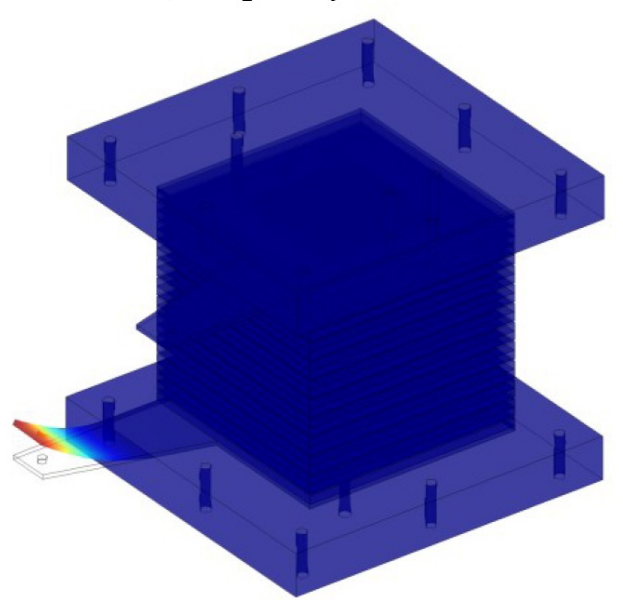

Mode 8, frequency $1117.3 \mathrm{~Hz}$. 
Figure 18. Natural vibration modeling of PEM fuel cell stack. First eight natural mode shapes in the eleven-cell stack at operation conditions [42].

\section{Conclusion}

CFD technology can be efficiently employed to analyze and develop a deeper understanding of the complex interaction between the PEM fuel cell components and the processes that occur inside it, that would be not possible by experimental techniques alone. There are some interesting and promising new results using CFD technology in PEM fuel cell development, that have been explored particularly for what concerns: innovative designs, innovative algorithm, maximum power and long cell life, air breathing PEM fuel cells, micro PEM fuel cells, micro air breathing PEM fuel cells, mechanical and hygro-thermal stresses in the PEM fuel cells, natural vibration of the PEM fuel cell stacks, and integrated PEM fuel cells. These innovative improvements will show a new scenario for the future fuel cell market of the next years.

\section{References}

1. Maher A.R. Sadiq Al-Baghdadi; Applications of Computational Fluid Dynamics (CFD) technology in engineering education. International Journal of Energy and Environment (IJEE) 2019, 10, 1-14.

2. Maher A.R. Sadiq AI-Baghdadi. CFD Models for Analysis and Design of PEM Fuel Cells; NOVA SCIENCE PUBLISHERS, INC, 400 Oser Avenue, Suite 1600, Hauppauge, NY 11788-3619 USA: ISBN-13: 9781604569971, 2008; pp. 1-202.

3. Maher A.R. Sadiq Al-Baghdadi; Modelling of proton exchange membrane fuel cell performance based on semi-empirical equations. Renewable Energy Journal 2005, 30, 1587-1599.

4. Maher A.R. Sadiq Al-Baghdadi; A simple mathematical model of performance for proton exchange membrane fuel cell. International Journal of Sustainable Energy 2007, 26, 79-90.

5. Maher A.R. Sadiq Al-Baghdadi; Numerical analysis of a proton exchange membrane fuel cell: Part I. Model development. Proceedings of the I MECH ENG. Journal of Power and Energy 2007, 221, 917-929.

6. Maher A.R. Sadiq Al-Baghdadi; Numerical analysis of a proton exchange membrane fuel cell: Part II. Parametric study. Proceedings of the I MECH ENG. Journal of Power and Energy 2007, 221, 931-939.

7. Maher A.R. Sadiq Al-Baghdadi; Performance, Water and Thermal Management, and Mechanical Related Failure in PEM Fuel Cells A CFD Study. Journal of Mechatronics, Electrical Power, and Vehicular Technology 2016, 7, 7-20.

8. Maher A.R. Sadiq Al-Baghdadi. "Fuel Cell Research Trends", (Chapter seven: PEM Fuel Cell Modeling); L. O. Vasquez, Eds.; NOVA SCIENCE PUBLISHERS, INC, 400 Oser Avenue, Suite 1600, Hauppauge, NY 11788-3619 USA: ISBN-13: 9781600216695, 2007; pp. 273-379.

9. Maher A.R. Sadiq Al-Baghdadi; Studying the effect of material parameters on cell performance of tubular-shaped PEM fuel cell. Energy Conversion \& Management 2008, 49, 2986-2996.

10. Maher A.R. Sadiq Al-Baghdadi; Analysis of Transport Phenomena and Electrochemical Reactions in a Micro PEM Fuel Cell. International Journal of Energy and Environment (IJEE) 2014, 5, 1-22.

11. Maher A.R. Sadiq Al-Baghdadi; Analysis of Transport Phenomena and Electrochemical Reactions in a Micro PEM Fuel Cell with Serpentine Gas Flow Channels. International Journal of Energy and Environment (IJEE) 2014, 5, 139-154.

12. Maher A.R. Sadiq Al-Baghdadi; Analysis of Transport Phenomena and Electrochemical Reactions in a Micro PEM Fuel Cell with Nature Inspired Flow Field Design. International Journal of Energy and Environment (IJEE) 2015, 6, 1-16.

13. Maher A.R. Sadiq Al-Baghdadi. Polymer Electrolyte Membrane Fuel Cells and Electrocatalysts - chapter four: CFD Models for Analysis and Design of Ambient Air-Breathing PEM Fuel Cells; Antonio Conti and Richard Esposito, Eds.; NOVA SCIENCE PUBLISHERS, INC, 400 Oser Avenue, Suite 1600, Hauppauge, NY 11788-3619 USA: ISBN-13: 9781606927731, 2009 ; pp. $123-166$.

14. Maher A.R. Sadiq Al-Baghdadi. Multiphase Flow Research - Chapter fourteen: CFD Modelling of Multiphase Flow: Application to AirBreathing PEM Fuel Cells; J. R. Williams and S Martin, Eds.; NOVA SCIENCE PUBLISHERS, INC, 400 Oser Avenue, Suite 1600, Hauppauge, NY 11788-3619 USA: ISBN-13: 9781606924488, 2009; pp. 769-811.

15. Maher A.R. Sadiq Al-Baghdadi; Three-dimensional computational fluid dynamics model of a tubular-shaped ambient air-breathing PEM fuel cell. Proceedings of the I MECH ENG. Journal of Power and Energy 2008, 222, 569-585.

16. Maher A.R. Sadiq Al-Baghdadi; Studying the effect of operating parameters on cell performance of tubular-shaped PEM fuel cell. Fuel Cell 2008, 8, 32-38.

17. Maher A.R. Sadiq Al-Baghdadi; Three-dimensional computational fluid dynamics model of a tubular-shaped PEM fuel cell. 
Renewable Energy Journal 2008, 33, 1334-1345.

18. Maher A.R. Sadiq Al-Baghdadi. Fuel Cell Performance - Chapter two: Performance Analysis and Optimization of Planar and TubularShaped PEM Fuel Cells; Zhidan Liu, Eds.; NOVA SCIENCE PUBLISHERS, INC, 400 Oser Avenue, Suite 1600, Hauppauge, NY 11788-3619 USA: ISBN-13: 9781621000556,$2012 ;$ pp. 61-118.

19. Maher A.R. Sadiq Al-Baghdadi; Performance comparison between airflow-channel and ambient air-breathing PEM fuel cells using three-dimensional computational fluid dynamics models. Renewable Energy Journal 2009, 34, 1812-1824.

20. Maher A.R. Sadiq Al-Baghdadi; Performance comparison between planar and tubular-shaped ambient air-breathing PEM fuel cells using three-dimensional computational fluid dynamics models. Journal of Renewable and Sustainable Energy 2009, 1, 023105-1 023105-15.

21. Maher A.R. Sadiq Al-Baghdadi. CFD Modeling and Analysis of Different Novel Designs of Air-Breathing PEM Fuel Cells; NOVA SCIENCE PUBLISHERS, INC, 400 Oser Avenue, Suite 1600, Hauppauge, NY 11788-3619 USA: ISBN-13: 9781608764891, 2010; pp. 1-202.

22. Maher A.R. Sadiq Al-Baghdadi; A CFD analysis of transport phenomena and electrochemical reactions in a tubular-shaped ambient air-breathing PEM micro fuel cell. The Hong Kong Institution of Engineers Transactions (HKIE Transactions) 2010, 17, 1-8.

23. Maher A.R. Sadiq AI-Baghdadi; CFD modelling of ambient air-breathing PEM fuel cells for portable devices. Fuel Cell 2008, 8, 6-14.

24. Maher A.R. Sadiq Al-Baghdadi; CFD modelling of ambient air-breathing PEM fuel cells for portable devices. Fuel Cell 2008, 8, 1-8.

25. Maher A.R. Sadiq Al-Baghdadi; Novel design of a compacted micro-structured air-breathing PEM fuel cell as a power source for mobile phones. International Journal of Energy and Environment (IJEE) 2010, 1, 555-572.

26. Maher A.R. Sadiq Al-Baghdadi; Novel Design of a Disk-Shaped Compacted Micro-Structured Air-Breathing PEM Fuel Cell. International Journal of Energy and Environment (IJEE) 2012, 3, 161-180.

27. Maher A.R. Sadiq Al-Baghdadi; A CFD study of hygro-thermal stresses distribution in PEM fuel cell during regular cell operation. Renewable Energy Journal 2009, 34, 674-682.

28. Maher A.R. Sadiq Al-Baghdadi; Influence of the design parameters in a proton exchange membrane (PEM) fuel cell on the mechanical behaviour of the polymer membrane. Energy \& Fuels. An American Chemical Society Journal 2007, $21,2258-2267$.

29. Maher A.R. Sadiq Al-Baghdadi; Effect of operating parameters on the hygro-thermal stresses in proton exchange membranes of fuel cells. International Journal of Hydrogen Energy 2007, 32, 4510-4522.

30. Maher A.R. Sadiq Al-Baghdadi; Prediction of deformation and hygro-thermal stresses distribution in ambient air-breathing PEM fuel cells using three-dimensional CFD model. Recent Patents on Mechanical Engineering 2009, 2, 26-39.

31. Maher A.R. Sadiq Al-Baghdadi; Prediction of hygro-thermal stresses distribution in proton exchange membranes using threedimensional multi-phase computational fluid dynamics model. Proceedings of the I MECH ENG. Journal of Power and Energy 2007, 221, 941-953.

32. Maher A.R. Sadiq AI-Baghdadi; Influence of the operating parameters in a proton exchange membrane (PEM) fuel cell on the mechanical behavior of the polymer membrane. . Fuel Cell 2008, 8, 34-39.

33. Maher A.R. Sadiq Al-Baghdadi; Effect of PEM fuel cell operation on gas diffusion layers and membrane stresses. International Journal of Fluid Mechanics Research 2008, 35, 219-234.

34. Maher A.R. Sadiq Al-Baghdadi; Modeling optimizes PEM fuel cell performance using three-dimensional multi-phase computational fluid dynamics model. Energy Conversion \& Management 2007, 48, 3102-3119.

35. Maher A.R. Sadiq Al-Baghdadi; Optimization study of a PEM fuel cell performance using 3D multi-phase computational fluid dynamics model. Journal of Zhejiang University SCIENCE-A 2007, 8, 285-300.

36. Maher A.R. Sadiq Al-Baghdadi; Parametric and optimization study of a PEM fuel cell performance using three-dimensional computational fluid dynamics model. Renewable Energy 2007, 32, 1077-1101.

37. Maher A.R. Sadiq Al-Baghdadi; Modelling optimizes PEM fuel cells to extract peak energy from our fuels - a CFD study. Ovidius University Annals of Chemistry Journal 2007, 18, 31-36.

38. Maher A.R. Sadiq Al-Baghdadi; Optimum operating point of PEM fuel cells to extract peak energy from our fuels. Fuel Cell 2007, 7, 36-38.

39. Maher A.R. Sadiq Al-Baghdadi. Thermal Stresses: Design, Behavior and Applications - Chapter one: Design Optimization of PEM Fuel Cells to Minimize the Maximum Thermal Stress; Alfred R. Webb, Eds.; NOVA SCIENCE PUBLISHERS, INC, 400 Oser Avenue, Suite 1600, Hauppauge, NY 11788-3619 USA: ISBN-13: 9781634853736, 2016; pp. 1-60.

40. Maher A.R. Sadiq Al-Baghdadi. PEM Fuel Cells: Theory, Performance and Applications - Chapter three: CFD Analysis of the Clamping Pressure Distribution in Running PEM Fuel Cell; Felicia Buchanan, Eds.; NOVA SCIENCE PUBLISHERS, INC, 400 Oser Avenue, Suite 1600, Hauppauge, NY 11788-3619 USA: ISBN-13: 9781634822275, 2015; pp. 111-166.

41. Maher A.R. Sadiq Al-Baghdadi. Computational Fluid Dynamics: Theory, Analysis and Applications - Chapter one: Computational Modeling Aspects of Polymer Electrolyte Fuel Cell Durability; Alyssa D. Murphy, Eds.; NOVA SCIENCE PUBLISHERS, INC, 400 Oser Avenue, Suite 1600, Hauppauge, NY 11788-3619 USA: ISBN-13: 9781612092768, 2011; pp. 1-40.

42. Maher A.R. Sadiq AI-Baghdadi. PEM FUEL CELLS - From Fundamentals to Research Studies; International Energy and Environment Foundation (IEEF): ISBN-13: 9798634858883, 2020; pp. 478.

\section{Keywords}




\section{Encyclopedia}

PEM fuel cell; CFD; Modeling; Performance; Mechanical stress; Hygro-thermal stresses; Durability; Ambient air-breathing; Micro fuel cell; Novel design; Stack; Hydrogen.

(c) (i) (C) 2020 by the author(s). Distribute under a Creative Commans CC BY license 